\title{
Tribological Behaviors of Vacuum Hot-Pressed Ceramic Composites with Enhanced Cyclic Oxidation and Corrosion
}

\section{Resistance}

Xuewu Li ${ }^{\text {a,b,c }}$, Jingsong Liang ${ }^{\text {a }}$, Tian Shi ${ }^{\mathrm{a}, *}$, Danni Yang ${ }^{\mathrm{a}}$, Xinchun Chen ${ }^{\mathrm{b}, *}$, Chuanwei Zhang ${ }^{\text {a }}$, Zhaohui Liu ${ }^{\mathrm{d}}$, Dianzi Liu ${ }^{\mathrm{e}}$, Qiaoxin Zhang ${ }^{\mathrm{d}} *$

a School of Mechanical Engineering, Xi'an University of Science and Technology, Xi'an 710054, China

b State Key Laboratory of Tribology, Tsinghua University, Beijing 100084, China

c Shandong Key Laboratory of Corrosion Science, Institute of Oceanology, Chinese Academy of Sciences, Qingdao 266071, China

d School of Mechanical and Electronic Engineering, Wuhan University of Technology, 122 Luoshi Road, Wuhan 430070, China

e Engineering Division, Faculty of Science, University of East Anglia, Norwich NR4 7TJ, England

*Corresponding authors.

E-mail addresses: tianshi@xust.edu.cn (T. Shi), chenxc1213@mail.tsinghua.edu.cn (X.C. Chen), zhangqx@whut.edu.cn (Q.X. Zhang) 


\begin{abstract}
Wear failure is a bottleneck restricting applications and developments of $\mathrm{Ti}_{3} \mathrm{SiC}_{2}$ ceramic. Particles reinforced composites provide an effective strategy to resist wear. In this work, $\mathrm{Ti}(\mathrm{C}, \mathrm{N})$ particles are used as reinforcements, and $\mathrm{Ti}_{3} \mathrm{SiC}_{2} / \mathrm{Ti}(\mathrm{C}, \mathrm{N})$ composite is fabricated by vacuum hot-pressing. Scanning electron microscopy (SEM), energy dispersive spectrometer (EDS) and X-ray diffract meter (XRD) are used to investigate composite morphologies, compositions and phases before and after hot-pressing. Meanwhile, high-temperature cyclic oxidations and tribological behaviors of composites under various loads, speeds and $\operatorname{Ti}(\mathrm{C}, \mathrm{N})$ contents are characterized. Results show that as-prepared composite is relatively dense, and $\mathrm{Ti}(\mathrm{C}, \mathrm{N})$ addition plays an important role in particle reinforcement of $\mathrm{Ti}_{3} \mathrm{SiC}_{2}$. Meanwhile, its hardness, wear resistance, cyclic oxidation resistance and corrosion resistance are significantly improved. In addition, wear characteristics and mechanisms of composites under different loads and speeds are analyzed in details. This work shows great potentials in developing engineering applications of ceramics, especially in high-temperature, oxidizing, frictional and corrosive environments.
\end{abstract}

Keywords: Ceramic material; Wear resistance; Cyclic oxidation; Particle reinforcement; Corrosion resistance 


\section{Introduction}

$\mathrm{Ti}_{3} \mathrm{SiC}_{2}$ ceramic is widely used in high-temperature structural components [1,2], electrical contact parts [3-5], welding parts [6], nuclear components [7,8], rotating equipments $[9,10]$ and anti-corrosion layers [11,12] due to excellent physical, chemical and mechanical behaviors $[13,14]$. $\mathrm{Ti}_{3} \mathrm{SiC}_{2}$ has prominent metallic properties [15], such as good thermal conductivity, electrical conductivity and ductility at room temperature [16]. It also possesses excellent ceramic behaviors, such as high yield strength, high melt point, high thermal stability, thermal-shock resistance and high strength [17]. More important, it can be processed by traditional machining, which is different from carbide ceramic [18]. Meanwhile, it has lower friction coefficient and superior self lubrication than molybdenum disulfide and graphite $[19,20]$. Such special behaviors make $\mathrm{Ti}_{3} \mathrm{SiC}_{2}$ widely used in electromechanical, instrumental, metallurgical, chemical, automotive, marine, national-defense and aerospace fields.

$\mathrm{Ti}_{3} \mathrm{SiC}_{2}$ also shows good high-temperature oxidation resistance and cyclic oxidation resistance. $\mathrm{Li}$ et al. [21] have investigated oxidability of $\mathrm{Ti}_{3} \mathrm{SiC}_{2}$ after oxidizing at 1000-1500 ${ }^{\circ} \mathrm{C}$ for $20 \mathrm{~h}$. Results show double-layer films with various compositions form on surface. The outer layer composes of $\mathrm{TiO}_{2}$, and the inner composes of $\mathrm{SiO}_{2}$ and $\mathrm{TiO}_{2}$. Both dense films are difficult to fall off at high temperature, and also display excellent oxidation resistance. Liu et al. [22] have discussed cyclic oxidation resistance of $\mathrm{Ti}_{3} \mathrm{SiC}_{2}$. It is found that obvious oxide layer composing of titanium dioxides form on surface after cyclic oxidation at $1100{ }^{\circ} \mathrm{C}$. Furthermore, few cracks develop on oxide layer suggesting that $\mathrm{Ti}_{3} \mathrm{SiC}_{2}$ acts out excellent resistance to 
high-temperature cyclic oxidation.

Under dry friction condition, contact regions of $\mathrm{Ti}_{3} \mathrm{SiC}_{2}$ ceramic only occur on its protrusions [23-25]. Elastic deformation of contact regions gradually turns into plastic deformation, resulting in continuously increased contact areas. Such ceramic suffers severe adhesive wear and aggravated abrasion due to its poor plastic deformation with growth of friction speed and load [26-28]. Generally, friction coefficient of $\mathrm{Ti}_{3} \mathrm{SiC}_{2}$ is larger than 0.5 in case of dry friction $[29,30]$. Friction heat gradually accumulates on ceramic, causing a continuous temperature rise on grinding surface [31,32]. As a result, cracks and grain fractures develop on ceramic under such heat effect. In addition, micro pores inevitably occur on $\mathrm{Ti}_{3} \mathrm{SiC}_{2}$, which brings about stress concentration, reduced ceramic strength and hardness [33]. Hence, wear resistance of $\mathrm{Ti}_{3} \mathrm{SiC}_{2}$ ceramic at high temperature is seriously threatened, which limits its applications in engineering fields.

$\mathrm{Ti}(\mathrm{C}, \mathrm{N})$ is a promising ceramic with prominent physical, chemical and mechanical properties, such as acid-alkali resistance, high melting point, high strength, high hardness, good chemical stability, corrosion resistance and wear resistance [34,35], which exactly compensates for shortcomings of $\mathrm{Ti}_{3} \mathrm{SiC}_{2}$. Herein, $\mathrm{Ti}_{3} \mathrm{SiC}_{2}$ powders are prepared by pressureless sintering at $1400{ }^{\circ} \mathrm{C}$. Then with the aid of vacuum hot-pressing, $\mathrm{Ti}_{3} \mathrm{SiC}_{2} / \mathrm{Ti}(\mathrm{C}, \mathrm{N})$ material is achieved. Results show that as-prepared composite exhibits superior resistances to wear, oxidation and corrosion. This work sheds positive insights in fabricating multifunctional ceramic composites for fulfilling engineering needs that traditional materials cannot meet under high-temperature, 
oxidizing, frictional and corrosive environments.

\section{Materials and methods}

\subsection{Materials}

Table 1 shows average granularities and purities of raw materials used in this work. Ti, SiC, TiC, Al and Ti(C,N) powders were purchased from Haocheng Metal Co., Ltd., Shanghai, China. Other reagents used with analytical grades were provided by Shaanxi Chemical Industry Co., Ltd., Xi'an, China.

\subsection{Procedures}

Powders were mixed according to a stoichiometric ratio of $\mathrm{n}(\mathrm{Ti}): \mathrm{n}(\mathrm{SiC}): \mathrm{n}(\mathrm{TiC}): \mathrm{n}(\mathrm{Al})=4: 2: 1: 0.2$. Ball milling was processed by placing mixed powders and absolute ethanol in a vacuum stainless steel tank installed on planetary ball mill. In milling process, grinding ball was made of stainless steel, ball to powder weight ratio was $4: 1$, grinding time was $24 \mathrm{~h}$ and rotating speed was $200 \mathrm{r} / \mathrm{min}$. After milling and drying, homogeneously mixed reactants were obtained. Then reactants were put in an alumina crucible and sintered in a vacuum furnace (ZT-15-20, Chenhua Electric Furnace Co., Ltd., Shanghai, China) at $1280{ }^{\circ} \mathrm{C}$. After grinding sintered products with agate bowl, $\mathrm{Ti}_{3} \mathrm{SiC}_{2}$ powders were achieved.

$\operatorname{Ti}(\mathrm{C}, \mathrm{N})$ powders with various mass fractions $(5,10,15,20 \mathrm{wt} \%)$ were mixed with the resultant $\mathrm{Ti}_{3} \mathrm{SiC}_{2}$. The maximum $\mathrm{Ti}(\mathrm{C}, \mathrm{N})$ mass fraction of $20 \mathrm{wt} \%$ was achieved by optimizing composite hardness. After adding absolute ethanol and milling for $24 \mathrm{~h}$, uniformly mixed slurry was achieved, and homogeneously reactants were obtained with further drying and passing through a 120 mesh sieve. Then compaction treatment 
was conducted by adding reactants in a circular stainless steel mold on a tablet machine (FYD, Sitron Precision Technology Development Co., Ltd., Tianjin, China) with $30 \mathrm{MPa}$ molding pressure and $4 \%$ paraffin molding agent. After drying in air, dewaxing was proceeded in an argon atmosphere furnace at $400{ }^{\circ} \mathrm{C}$ for $1 \mathrm{~h}$ with a temperature rise rate of $5{ }^{\circ} \mathrm{C} / \mathrm{min}$. Then dewaxed mixture was placed in a vacuum carbon tube furnace and sintered with a temperature rise rate of $10{ }^{\circ} \mathrm{C} / \mathrm{min}$ at 1250 , 1300, 1350 and $1400{ }^{\circ} \mathrm{C}$. The maximum sintering temperature of $1400{ }^{\circ} \mathrm{C}$ was determined by optimizing composite hardness. Heat preservation was kept for $1 \mathrm{~h}$ after sintering. Finally, $\mathrm{Ti}_{3} \mathrm{SiC}_{2} / \mathrm{Ti}(\mathrm{C}, \mathrm{N})$ composite was achieved after cooling in vacuum condition.

\subsection{Characterization}

X-ray diffract meter (XRD, D/MAX-RB, Japan), scanning electron microscopy (SEM, JSM-5610LV, Japan) and energy dispersive spectrometer (EDS, Phoenix, USA) were used to analyze chemical phases, micro morphologies and surface compositions, respectively. Polarization curve and electrochemical impedance spectroscopy were obtained by electrochemical workstation (CHI660E, China) for characterizing corrosion resistances of $\mathrm{Ti}_{3} \mathrm{SiC}_{2} / \mathrm{Ti}(\mathrm{C}, \mathrm{N})$ composites. Polarization curve was recorded from -0.5 to $2.5 \mathrm{~V}$ with $1 \mathrm{mV} / \mathrm{s}$ scan rate. Impedance spectrum was recorded with 10 $\mathrm{mV}$ amplitude from $10^{-2}$ to $10^{5} \mathrm{~Hz}$. Vickers hardness tester (HVS-1000, China) was used to measure sample hardness with an applied pressure of $10 \mathrm{~N}$ for $10 \mathrm{~s}$. The final hardness was achieved by averaging three measurements. Measured density $\left(\rho_{\mathrm{m}}\right)$ of sample was determined using Archimedes principle [36]: 


$$
\rho_{\mathrm{m}}=\frac{A}{A-B}\left(\rho_{1}-\rho_{2}\right)+\rho_{2}
$$

where $\rho_{1}$ and $\rho_{2}$ respectively referred to auxiliary liquid density and air density $\left(0.0012 \mathrm{~g} / \mathrm{cm}^{3}\right), A$ and $B$ denoted to sample masses in air and auxiliary liquid, respectively. Theoretical density $\left(\rho_{\mathrm{t}}\right)$ was calculated according to the composite rule [37]:

$$
\rho_{\mathrm{t}}=\frac{\rho_{\mathrm{a}} \rho_{\mathrm{b}}}{n_{\mathrm{a}} \rho_{\mathrm{b}}+n_{\mathrm{b}} \rho_{\mathrm{a}}}
$$

where $\rho_{\mathrm{a}}$ and $\rho_{\mathrm{b}}$ respectively represented theoretical densities of $\mathrm{Ti}_{3} \mathrm{SiC}_{2}$ and $\mathrm{Ti}(\mathrm{C}, \mathrm{N}), n_{a}$ and $n_{\mathrm{b}}$ respectively indicated mass percentages of $\mathrm{Ti}_{3} \mathrm{SiC}_{2}$ and $\mathrm{Ti}(\mathrm{C}, \mathrm{N})$. Relative density $\left(\rho_{\mathrm{r}}\right)$ of composite was expressed as:

$$
\rho_{\mathrm{r}}=\frac{\rho_{\mathrm{m}}}{\rho_{\mathrm{t}}} \times 100 \%
$$

High-temperature ball-disk friction and wear tester (HT-1000, Zhongke Kaihua Technology Development Co., Ltd., Lanzhou, China) was used for tribological test. GCr15 steel ball with $5 \mathrm{~mm}$ diameter was used. Before test, as-prepared composite was polished by buffing machine, and then ultrasonically cleaned with absolute ethanol. The test was processed under room-temperature and dry-friction conditions for $20 \mathrm{~min}$ with $3 \mathrm{~mm}$ rotation radius. Comparative experiments were also conducted under various loads and rotation speeds. Instantaneous friction coefficient was measured and averaged as the final friction coefficient. Wear rate $(W)$ was determined by weighing mass changes before and after friction test, which was related to mass loss $(\Delta M)$, test load $(N)$ and sliding distance $(S)$ :

$$
W=\frac{\Delta M}{N S}
$$


$\mathrm{Ti}_{3} \mathrm{SiC}_{2} / \mathrm{Ti}(\mathrm{C}, \mathrm{N})$ composite obtained from vacuum hot-pressing was cut into strips by wire electrical-discharge machining, then polished, ultrasonically cleaned and dried. $\mathrm{Al}_{2} \mathrm{O}_{3}$ crucible was also ultrasonically cleaned with absolute ethanol to remove impurities and oil stains. $\mathrm{Ti}_{3} \mathrm{SiC}_{2} / \mathrm{Ti}(\mathrm{C}, \mathrm{N})$ composite was put in $\mathrm{Al}_{2} \mathrm{O}_{3}$ crucible for incubating at 800,1000 and $1200{ }^{\circ} \mathrm{C}$ for $50 \mathrm{~min}$ in box furnace. Afterwards, it was cooled in drying oven for $10 \mathrm{~min}$. The above process represented an oxidation cycle. Finally, mass changes before and after oxidation were calculated for determining relationships with cycle numbers and analyzing composite oxidation kinetics.

\section{Results and discussion}

\subsection{Composition, structure and property of $\mathrm{Ti}_{3} \mathrm{SiC}_{2} / \mathrm{Ti}(\mathrm{C}, \mathrm{N})$ composite}

Fig. 1 shows $\mathrm{SEM}$ image and $\mathrm{XRD}$ pattern of $\mathrm{Ti}_{3} \mathrm{SiC}_{2}$ powders. As seen, as-prepared powders display plate-like hexagonal-crystal structures, and they are uniformly distributed with sizes of about 5-10 $\mu \mathrm{m}$. The main diffraction peaks in XRD results are corresponding to $\mathrm{Ti}_{3} \mathrm{SiC}_{2}$ materials. Meanwhile, a small amount of TiC peaks are observed, suggesting that as-prepared powders mainly compose of $\mathrm{Ti}_{3} \mathrm{SiC}_{2}$ besides slight $\mathrm{TiC}$ materials.

Fig. 2a shows XRD patterns of $\mathrm{Ti}_{3} \mathrm{SiC}_{2} / \mathrm{Ti}(\mathrm{C}, \mathrm{N})$ composites sintered at $1400{ }^{\circ} \mathrm{C}$ with different $\mathrm{Ti}(\mathrm{C}, \mathrm{N})$ mass fractions. XRD patterns of $\mathrm{Ti}_{3} \mathrm{SiC}_{2} / \mathrm{Ti}(\mathrm{C}, \mathrm{N})$ materials sintered with 20 wt $\% \mathrm{Ti}(\mathrm{C}, \mathrm{N})$ at various temperatures are illustrated in Fig. $2 \mathbf{b}$. It is seen that the main components of as-prepared composites are $\mathrm{Ti}_{3} \mathrm{SiC}_{2}$ and $\mathrm{Ti}(\mathrm{C}, \mathrm{N})$ accompanied by small amounts of $\mathrm{SiC}$ and $\mathrm{TiC}$. Meanwhile, a relatively dense composite surface is achieved after sintering at $1400{ }^{\circ} \mathrm{C}$ with $20 \mathrm{wt} \% \mathrm{Ti}(\mathrm{C}, \mathrm{N})$, as seen 
in Fig. 2c. Fig. 2d and e are corresponding to cross-section SEM images of the sample in Fig. 2c. As seen, typical plate-like structures fracturing along cleavage planes are $\mathrm{Ti}_{3} \mathrm{SiC}_{2}$ phases. It is also found that fine $\mathrm{Ti}(\mathrm{C}, \mathrm{N})$ particles distribute in $\mathrm{Ti}_{3} \mathrm{SiC}_{2}$ matrix.

Fig. 3a depicts measured densities and relative densities of composites sintered with $20 \mathrm{wt} \% \operatorname{Ti}(\mathrm{C}, \mathrm{N})$ at different temperatures. Clearly, relative density increases with sintering temperature. As temperature rises, shrinkage force generated from sintered body is enhanced leading to an increased material density [38]. Measured densities and relative densities of composites sintered at $1400{ }^{\circ} \mathrm{C}$ with various $\mathrm{Ti}(\mathrm{C}, \mathrm{N})$ mass fractions are displayed in Fig. 3b. As seen, both densities increase with $\operatorname{Ti}(\mathrm{C}, \mathrm{N})$ content. Since $\mathrm{Ti}(\mathrm{C}, \mathrm{N})$ density is higher than that of $\mathrm{Ti}_{3} \mathrm{SiC}_{2}$, composite density increases as $\operatorname{Ti}(\mathrm{C}, \mathrm{N})$ content rises.

Fig. 4a displays the relationship between sintering temperature and micro hardness of $\mathrm{Ti}_{3} \mathrm{SiC}_{2} / \mathrm{Ti}(\mathrm{C}, \mathrm{N})$ composites with $20 \mathrm{wt} \% \mathrm{Ti}(\mathrm{C}, \mathrm{N})$. It is seen that composite hardness increases with sintering temperature. As mentioned above, sample density showing positive correlation with hardness enhances with sintering temperature, so composite hardness also increases with temperature. However, composite hardness decreases when sintering temperature achieves $1450{ }^{\circ} \mathrm{C}$. Such an exorbitant temperature makes $\mathrm{Ti}(\mathrm{C}, \mathrm{N})$ particles gather in molten body, resulting in uneven heating of ceramic composite. Then composite hardness decreases under actions of reinforcement aggregation and thermal runaway. Therefore, the maximum sintering temperature of $1400{ }^{\circ} \mathrm{C}$ can be finally determined by optimizing composite hardness. 
Fig. 4b exhibits composite hardness sintered at $1400{ }^{\circ} \mathrm{C}$ with different $\mathrm{Ti}(\mathrm{C}, \mathrm{N})$ mass fractions. As seen, micro hardness increases with $\mathrm{Ti}(\mathrm{C}, \mathrm{N})$ mass fraction. When $\operatorname{Ti}(\mathrm{C}, \mathrm{N})$ mass fraction increases to $20 \mathrm{wt} \%$, a greatly enhanced hardness of $6.81 \mathrm{GPa}$ is achieved. As typical hard phases [39], the addition of $\operatorname{Ti}(\mathrm{C}, \mathrm{N})$ ceramics acting as particles for reinforcing $\mathrm{Ti}_{3} \mathrm{SiC}_{2}$ matrix significantly increases composite hardness. However, composite hardness decreases when $\operatorname{Ti}(\mathrm{C}, \mathrm{N})$ mass fraction exceeds $20 \mathrm{wt} \%$. Exorbitant $\operatorname{Ti}(\mathrm{C}, \mathrm{N})$ content makes melt viscosity rise and fluidity decline. As a result, composite porosity and impurity increase, directly leading to the decrease of composite density and hardness. Hence, the maximum Ti(C,N) mass fraction of 20 $\mathrm{wt} \%$ is achieved by optimizing composite hardness.

\subsection{Effect of $\mathrm{Ti}(\mathrm{C}, \mathrm{N})$ content on tribological property}

Instantaneous friction coefficients versus time for composites with different $\mathrm{Ti}(\mathrm{C}, \mathrm{N})$ contents at low speed $(0.1 \mathrm{~m} / \mathrm{s})$ and light load $(5 \mathrm{~N})$ are achieved in Fig. 5a. Fig. 5b shows instantaneous friction coefficients versus time for composites with different $\operatorname{Ti}(\mathrm{C}, \mathrm{N})$ contents at high speed $(0.4 \mathrm{~m} / \mathrm{s})$ and heavy load $(20 \mathrm{~N})$. Comparatively, larger fluctuations of friction coefficients are found for high speeds and heavy loads. Furthermore, both fluctuation ranges of composites with high $\mathrm{Ti}(\mathrm{C}, \mathrm{N})$ contents are larger than the low ones, and the same is true for friction coefficients.

Fig. 6a and b respectively exhibit average friction coefficients and wear rates versus $\operatorname{Ti}(\mathrm{C}, \mathrm{N})$ contents for composites at various speeds and loads. Under a low speed and light load condition, friction coefficient increases first and then decreases, but the corresponding wear rate decreases as $\operatorname{Ti}(\mathrm{C}, \mathrm{N})$ content increases. Under a high 
speed and heavy load condition, both friction coefficient and wear rate increase with $\operatorname{Ti}(\mathrm{C}, \mathrm{N})$ contents.

Under a low speed $(0.1 \mathrm{~m} / \mathrm{s})$ and light load $(5 \mathrm{~N})$ condition, Fig. 7a and b show surface morphologies of frictional composites with Ti(C,N) contents of 5 and 20 wt $\%$, respectively. More and deeper furrows are found in Fig. 7a, suggesting that low $\operatorname{Ti}(\mathrm{C}, \mathrm{N})$ content is easy to develop plastic deformation on composite for its inadequate material hardness thereby making a poor resistance to furrows in the case of low speed and light load [40]. Hence, friction coefficient of composite increases and wear rate is large at this stage. For a high $\operatorname{Ti}(\mathrm{C}, \mathrm{N})$ content in Fig. 7b, however, relatively shallow furrows are observed. When $\operatorname{Ti}(\mathrm{C}, \mathrm{N})$ content is high, it is hard to produce plastic deformation on composite for its enhanced hardness thereby making a strong resistance to furrows. So the corresponding friction coefficient gradually decreases, and wear rate is small, which is consistent with the data trends in Fig. 5 and 6.

Under a high speed $(0.4 \mathrm{~m} / \mathrm{s})$ and heavy load $(20 \mathrm{~N})$ condition, Fig. 8a and b display surface morphologies of frictional composites with Ti(C,N) contents of 5 and $20 \mathrm{wt} \%$, respectively. Fig. 8c and $\mathbf{d}$ correspond to EDS spectra of composites in Fig. 8a and b, respectively. Rough transfer fragments with numerous Fe elements are found in Fig. 8a and c. It shows that Fe elements in steel ball transfer and adhere to composite surface during frictional process thereby resulting in severe adhesive wear. When $\operatorname{Ti}(\mathrm{C}, \mathrm{N})$ content reaches 20 wt $\%$ (Fig. 8b), composite surface is relatively smooth accompanied by some groove marks, transfer fragments and pits induced by particle detachment. Meanwhile, Fe and O elements develop on surface (Fig. 8d) 
indicating that both adhesive wear and oxidative wear occur in frictional process. The increase of frictional speed will cause a sharp rise of surface temperature [41]. Furthermore, temperature distribution and stress distribution are uneven on such a rough contact surface. Therefore, for a low $\operatorname{Ti}(\mathrm{C}, \mathrm{N})$ content, load-carrying micro protrusions produce plastic deformation and adhesive wear thereby resulting in low friction coefficient and wear rate. For a high $\operatorname{Ti}(\mathrm{C}, \mathrm{N})$ content, it will cause adhesive wear and oxidative wear of micro protrusions. Under further action of frictional shear force, hard phases in composite are peeled off as abrasive particles, eventually leading to furrow formation, increased friction coefficient and wear rate, as exhibited in Fig. $\mathbf{5}$ and 6 .

\subsection{Effect of load and speed on tribological property}

Friction coefficients and wear rates versus applied loads for composites with 20 wt\% $\mathrm{Ti}(\mathrm{C}, \mathrm{N})$ at different speeds are achieved in Fig. 9a and b, respectively. As seen, friction coefficients decrease with the increase of loads, but wear rates increase with loads at $0.1 \mathrm{~m} / \mathrm{s}$. Both friction coefficients and wear rates decrease as loads increase at $0.2 \mathrm{~m} / \mathrm{s}$. At speeds of 0.3 and $0.4 \mathrm{~m} / \mathrm{s}$, friction coefficients and wear rates decrease first and then increase with loads.

Under a heavy load condition (20 N), Fig. 10a and b display surface morphologies of frictional composites with $20 \mathrm{wt} \% \mathrm{Ti}(\mathrm{C}, \mathrm{N})$ at 0.1 and $0.2 \mathrm{~m} / \mathrm{s}$, respectively. Fig. 10c and $\mathbf{d}$ respectively refer to EDS spectra of composites in Fig. 10a and b. Few furrows are found on composite for its high $\operatorname{Ti}(\mathrm{C}, \mathrm{N})$ content and micro hardness, as shown in Fig. 10a. But transfer fragments and a small amount of film products are 
observed on surface. More film products are also seen in Fig. 10b. The corresponding EDS spectrum shows that the main elements of films are $\mathrm{Ti}, \mathrm{Si}, \mathrm{Al}$ and $\mathrm{O}$ indicating mixtures of $\mathrm{Ti}, \mathrm{Si}$ and $\mathrm{Al}$ oxides. There is also slight $\mathrm{Fe}$ element suggesting mild adhesive wear on composite surface. At $0.1 \mathrm{~m} / \mathrm{s}$, plastic deformation occurs on composite surface so that its friction coefficient decreases with the increase of load, while wear rate increases with load. Meanwhile, abrasive wear mainly occurs at this stage. At $0.2 \mathrm{~m} / \mathrm{s}$, more oxide films form on composite making friction coefficient and wear rate decrease with the increase of load. Therefore oxide film wear mainly occurs at this stage [42].

Under a rotation speed of $0.3 \mathrm{~m} / \mathrm{s}$, Fig. 11a and b show surface morphologies of frictional composites with $20 \mathrm{wt} \% \mathrm{Ti}(\mathrm{C}, \mathrm{N})$ at 5 and $15 \mathrm{~N}$, respectively. Fig. 11c and d respectively display enlarged SEM images of Fig. 11a and b. Fig. 11e and $\mathbf{f}$ exhibit EDS spectra of composites in Fig. 11a and b, respectively. As seen, oxide films also form on composites. Compared with low speeds (Fig. 10), such films are more uniform, continuous and dense, suggesting that frictional surfaces are easier to oxidize as speeds increase. By observing enlarged image in Fig. 11c, oxide film covered with a small amount of particles is uniform and continuous at $5 \mathrm{~N}$. These particles act as abrasive grains for forming micro grooves on film. At $15 \mathrm{~N}$, cracks develop on oxide film (Fig. 11d), which may be fatigue cracks under cyclic stress [43]. The increase of load tends to destroy oxide film at $0.3 \mathrm{~m} / \mathrm{s}$. As seen in EDS spectra (Fig. 11e-f), the main components of oxide films on frictional surfaces are $\mathrm{Ti}, \mathrm{Si}, \mathrm{O}$ and $\mathrm{Fe}$. With increases in speed and load, $\mathrm{O}$ and $\mathrm{Fe}$ contents raise indicating aggravated oxidation 
on composite and intensified element transfer between friction pairs. Under low load conditions, friction coefficients and wear rates decrease as loads increase because of oxide films, which play key roles in lubricating interfaces. Meanwhile, oxide film wear occurs on composite. When applied load reaches $15 \mathrm{~N}$, cracks develop on composite. As load continues to increase, composite surface is subject to severe adhesive wear, and oxide film is damaged. Combining with shearing action, hard phases in composites are peeled off to form micro pits. Hard phases also act as abrasive particles in friction process, and abrasive wear occurs [44,45]. As a result, both friction coefficient and wear rate of composites increase with loads. The above tribological behaviors versus applied loads at $0.3 \mathrm{~m} / \mathrm{s}$ are in accordance with the rotation speed of $0.4 \mathrm{~m} / \mathrm{s}$.

\subsection{Oxidation resistance of $\mathrm{Ti}_{3} \mathrm{SiC}_{2} / \mathrm{Ti}(\mathrm{C}, \mathrm{N})$ composite}

Fig. 12 shows the relationship between mass increments and oxidation cycle times of $\mathrm{Ti}_{3} \mathrm{SiC}_{2} / \mathrm{Ti}(\mathrm{C}, \mathrm{N})$ composites with $20 \mathrm{wt} \% \mathrm{Ti}(\mathrm{C}, \mathrm{N})$ at different oxidation temperatures. As seen, mass increments increase with cycle times. Cyclic oxidation process includes three stages. The first stage corresponds to the first 5 cycles. Oxide film forms quickly at this stage, exhibiting a sharp oxidation process. The second stage is from 5 to 35 cycles, in which oxidation mass increment rate is on the decline. At this stage, a dense oxide film forms on composite thereby slowing down its oxidation rate. The third stage indicates the cycle more than 35 times. At this stage, mass increment tends to be stable, because oxide film on surface is too dense to carry out oxidation reaction [46]. 
Fig. 15a-c exhibit cross-section SEM images of oxide layers on composites after 40 oxidation cycles at 800,1000 and $1200{ }^{\circ} \mathrm{C}$, respectively. At $800{ }^{\circ} \mathrm{C}, \mathrm{Ti}_{3} \mathrm{SiC}_{2}$ is oxidized to form a thin oxide film, and also its oxide grains are about $0.5 \mu \mathrm{m}$ wide and $3 \mu \mathrm{m}$ long. At $1000{ }^{\circ} \mathrm{C}$, oxide grains display clear outlines and sharp edges, which is due to freely grown grains without applied pressures during sintering. Meanwhile, owing to different growth environments and growth rates of grains, gaps form between grains leading to a loose oxide film [49]. Gaps also act as diffusion channels of oxygen atoms thereby causing rapidly oxidized composite surface, and the corresponding grain size is larger than that at $800{ }^{\circ} \mathrm{C}$. At $1200{ }^{\circ} \mathrm{C}, \mathrm{TiO}_{2}$ growth presents a lamellar epitaxy trend, and preferred orientation is obvious suggesting that $\mathrm{TiO}_{2}$ crystal grows outwards. Similarly, gaps also form between grains leading to oxygen atom diffusions for developing oxidation reaction. Finally, a gradually thickened oxide film comes into being.

\subsection{Corrosion resistance of $\mathrm{Ti}_{3} \mathrm{SiC}_{2} / \mathrm{Ti}(\mathrm{C}, \mathrm{N})$ composite}

Polarization curves recorded from -0.5 to $2.5 \mathrm{~V}$ with $1 \mathrm{mV} / \mathrm{s}$ scan rate for $\mathrm{Ti}_{3} \mathrm{SiC}_{2} / \mathrm{Ti}(\mathrm{C}, \mathrm{N})$ composites sintered at $1400{ }^{\circ} \mathrm{C}$ with various $\mathrm{Ti}(\mathrm{C}, \mathrm{N})$ mass fractions are achieved by electrochemical workstation in Fig. 16a. As seen, anode curves display obvious inflection points at about $0.50 \mathrm{~V}$, and then go through downward trends. All samples also exhibit passivating characterizations. After being fitted with Tafel extrapolation method [50], electrochemical parameters including corrosion potentials and current densities are achieved in Fig. 16a. Samples with high corrosion potentials and low current densities generally possess weak electron transfers thereby 
leading to superior corrosion resistances [51]. Corrosion inhibition rate $(\eta)$ is also used to evaluate corrosion resistances of composites:

$$
\eta=\frac{I_{\mathrm{a}}-I_{\mathrm{b}}}{I_{\mathrm{a}}} \times 100 \%
$$

where $I_{\mathrm{a}}$ and $I_{\mathrm{b}}$ stand for corrosion current densities of samples. The equation indicates that when $\operatorname{Ti}(\mathrm{C}, \mathrm{N})$ content increases to $20 \mathrm{wt} \%$, a greatly enhanced corrosion resistance $(\eta=86.51 \%)$ is achieved over $\mathrm{Ti}_{3} \mathrm{SiC}_{2}$ ceramic, and also corrosion resistances of composites increase with $\mathrm{Ti}(\mathrm{C}, \mathrm{N})$ contents.

To further characterize corrosion resistances of composites, electrochemical impedance spectra are recorded with $10 \mathrm{mV}$ amplitude from $10^{-2}$ to $10^{5} \mathrm{~Hz}$ in Fig. 16b. As seen, the largest capacitive arc for $20 \mathrm{wt} \% \operatorname{Ti}(\mathrm{C}, \mathrm{N})$ indicates the weakest charge transfer as well as greatly enhanced corrosion resistance, which is consistent with polarization result. On the one hand, composite density increases with $\operatorname{Ti}(\mathrm{C}, \mathrm{N})$ content, and its addition acts as particles for reinforcing $\mathrm{Ti}_{3} \mathrm{SiC}_{2}$ matrix. On the other hand, as a typical hard phase, $\mathrm{Ti}(\mathrm{C}, \mathrm{N})$ significantly improves composite hardness and corrosion resistance. In general, $\mathrm{Ti}(\mathrm{C}, \mathrm{N})$ reinforcements have effectively enhanced wear resistance, high-temperature cyclic oxidation resistance and corrosion resistance of $\mathrm{Ti}_{3} \mathrm{SiC}_{2}$ ceramics.

\section{Conclusions}

$\mathrm{Ti}_{3} \mathrm{SiC}_{2} / \mathrm{Ti}(\mathrm{C}, \mathrm{N})$ composites have been prepared in this work. The corresponding mechanical properties, tribological behaviors, high-temperature oxidation resistances and corrosion resistances have been investigated. The conclusions are as follows:

(1) The main phases in vacuum hot-pressed composites are $\mathrm{Ti}_{3} \mathrm{SiC}_{2}$ and $\mathrm{Ti}(\mathrm{C}, \mathrm{N})$. 
$\mathrm{Ti}_{3} \mathrm{SiC}_{2}$ phase shows plate-like hexagonal-crystal structures, and $\mathrm{Ti}(\mathrm{C}, \mathrm{N})$ phase exhibits granular characteristic thereby playing a role of particle reinforcement. Sintering temperature and $\operatorname{Ti}(\mathrm{C}, \mathrm{N})$ content have great influences on composite density and hardness. Measured density, relative density and hardness of composites increase with sintering temperatures, and also they increase with $\mathrm{Ti}(\mathrm{C}, \mathrm{N})$ contents.

(2) Under rotation speeds of $0.1-0.4 \mathrm{~m} / \mathrm{s}$ and applied loads of 5-20 N, friction coefficients of composites with $20 \mathrm{wt} \% \mathrm{Ti}(\mathrm{C}, \mathrm{N})$ change within a range of $0.33-0.58$, while wear rates in a range of $0.50-4.76 \times 10^{-6} \mathrm{~g} / \mathrm{Nm}$. Improved wear resistances of composites are mainly due to the increase of material hardness induced by $\operatorname{Ti}(\mathrm{C}, \mathrm{N})$ additions and the formation oxide films with good lubricating properties. Surface films mainly compose of mixed oxides of titanium and silicon. At low speed and light load conditions, plastic deformation occurs on composite leading to abrasive wears. As loads and speeds increase, wear mechanisms convert into adhesive wears, and it also shows boundary lubrication friction with oxide films.

(3) Oxidation extent of composite surface increases with temperatures and oxidation cycles. Cyclic oxidation process includes three stages. The first stage corresponds to a sharp oxidation process. At the second stage, a dense oxide film forms on surface thereby slowing down its oxidation rate. At the third stage, oxidation mass increment tends to be stable, because oxide film on surface is too dense to carry out oxidation reaction. Meanwhile, high-temperature grain growth is also along with material oxidation.

(4) Corrosion resistances of composites increase with $\mathrm{Ti}(\mathrm{C}, \mathrm{N})$ contents. $\mathrm{Ti}(\mathrm{C}, \mathrm{N})$ 
additions act as particles for reinforcing $\mathrm{Ti}_{3} \mathrm{SiC}_{2}$ matrix. Meanwhile, as a typical hard phase, $\operatorname{Ti}(\mathrm{C}, \mathrm{N})$ reinforcement significantly improves composite hardness and corrosion resistance.

\section{Acknowledgements}

This work is supported by the National Natural Science Foundation of China (No. 51905417, 51974229), Natural Science Foundation of Shaanxi Province (No. 2019JQ-793), Open Fund of Shandong Key Laboratory of Corrosion Science (No. KLCS201907), Innovation and Entrepreneurship Training Program for College Students in Shaanxi Province (No. S201910704028) and Excellent Youth Science and Technology Fund Project in Xi'an University of Science and Technology (No. 2019YQ3-09).

\section{References}

[1] P. Istomin, E. Istomina, A. Nadutkin, V. Grass, Fabrication of $\mathrm{Ti}_{3} \mathrm{SiC}_{2} / \mathrm{SiCp}$ multiport minichannel plates for high-temperature applications, J. Eur. Ceram. Soc. 39 (15) (2019) 4602-4608.

[2] H.H. Shen, X. Xiang, H.B. Zhang, X.S. Zhou, H.X. Deng, X.T. Zu, Effects of helium irradiation dose and temperature on the damage evolution of $\mathrm{Ti}_{3} \mathrm{SiC}_{2}$ ceramic, Chinese Physics B 28 (7) (2019) 076104.

[3] X.C. Huang, Y. Feng, G. Qian, Z.J. Zhou, Arc ablation properties of $\mathrm{Ti}_{3} \mathrm{SiC}_{2}$ material, Ceram. Int. 45 (16) (2019) 20297-20306.

[4] L.L. Zheng, X.C. Li, Q.S. Hua, Z.Q. Dai, T.Z. Zhang, Y.H. Qian, J.J. Xu, M.S. Li, Long-term oxidation and electrical behavior of $\mathrm{Nb}$-doped $\mathrm{Ti}_{3} \mathrm{SiC}_{2}$ as solid oxide 
fuel cell interconnects, J. Am. Ceram. Soc. 100 (7) (2017) 3155-3164.

[5] J.L. Lu, N. Abbas, J.N. Tang, R.T. Hu, G.M. Zhu, Characterization of $\mathrm{Ti}_{3} \mathrm{SiC}_{2}$-coating on stainless steel bipolar plates in simulated proton exchange membrane fuel cell environments, Electrochem. Commun. 105 (2019) 106490.

[6] Y. Wang, Y.H. Xia, Z.W. Yang, D.P. Wang, Interfacial Microstructure and Properties of Brazed Joints of $\mathrm{Ti}_{3} \mathrm{SiC}_{2}$ Ceramic and TC4 Alloy, Rare Metal Mat. Eng. 48 (9) (2019) 3041-3047.

[7] H.L. Zhang, R.R. Su, L.Q. Shi, D.J. O'Connor, B.V. King, E.H. Kisi, The damage evolution of He irradiation on $\mathrm{Ti}_{3} \mathrm{SiC}_{2}$ as a function of annealing temperature, $\mathrm{J}$. Eur. Ceram. Soc. 38 (4) (2018) 1253-1264.

[8] W.A. Hanson, M.K. Patel, M.L. Crespillo, Y.W. Zhang, W.J. Weber, Influence of electronic vs nuclear energy loss in radiation damage of $\mathrm{Ti}_{3} \mathrm{SiC}_{2}$, Acta Mater. 161 (2018) 302-310.

[9] C. Ang, S. Zinkle, C. Shih, C. Silva, N. Cetiner, Y. Katoh, Phase stability, swelling, microstructure and strength of $\mathrm{Ti}_{3} \mathrm{SiC}_{2}$ - $\mathrm{TiC}$ ceramics after low dose neutron irradiation, J. Nucl. Mater. 483 (2017) 44-53.

[10] Y. Wang, X.F. Wu, Z.W. Yang, Y.H. Xia, D.P. Wang, Microstructure and mechanical properties of $\mathrm{Ti}_{3} \mathrm{SiC}_{2} / \mathrm{Ti}_{3} \mathrm{SiC}_{2}$ diffusion bonded joints using $\mathrm{Ti}$ foil as an interlayer, Ceram. Int. 45 (16) (2019) 20900-20909.

[11] Y. Jiang, Y.H. He, Electrochemical corrosion behavior of micrometer-sized porous $\mathrm{Ti}_{3} \mathrm{SiC}_{2}$ compounds in $\mathrm{NaCl}$ solution, Mater. Corros. (2019) 1-6.

[12] X.L. Liu, Y. Jiang, H.B. Zhang, Y.H. He, Corrosion behavior of porous $\mathrm{Ti}_{3} \mathrm{SiC}_{2}$ 
in nitric acid and aqua regia, T. Nonferr. Metal. Soc. 27 (3) (2017) 584-590.

[13] F. Turki, H. Abderrazak, F. Schoenstein, F. Tetard, M. Abdellaoui, N. Jouini, Physico-chemical and mechanical properties of $\mathrm{Ti}_{3} \mathrm{SiC}_{2}$-based materials elaborated from $\mathrm{SiC} / \mathrm{Ti}$ by reactive spark plasma sintering, J. Adv. Ceram. 8 (1) (2019) 47-61.

[14] J.S. Yang, S.M. Dong, C.G. Xu, Mechanical response and microstructure of 2D carbon fiber reinforced ceramic matrix composites with $\mathrm{SiC}$ and $\mathrm{Ti}_{3} \mathrm{SiC}_{2}$ fillers, Ceram. Int. 42 (2) (2016) 3019-3027.

[15] Q.D. Xiao, F. Zhou, S. Wu, $\mathrm{Ti}_{3} \mathrm{SiC}_{2}$ friction material prepared by novel method of infiltration sintering, Adv. Appl. Ceram. 116 (1) (2017) 2-7.

[16] B.Q. Li, Z.L. Yang, M.F. Chu, Q.Q. Huang, Z.Y. Wang, R. Gao, Y. Zhong, X.X. Liu, L.M. Duan, P.C. Zhang, $\mathrm{Ti}_{3} \mathrm{SiC}_{2} / \mathrm{UO}_{2}$ composite pellets with superior high-temperature thermal conductivity, Ceram. Int. 44 (16) (2018) 19846-19850.

[17] S. Gupta, M.F. Riyad, Synthesis and tribological behavior of novel UHMWPE-Ti ${ }_{3} \mathrm{SiC}_{2}$ composites, Polym. Composite. 39 (1) (2018) 254-262.

[18] M.A. Lagos, C. Pellegrini, I. Agote, N. Azurmendi, J. Barcena, M. Parco, L. Silvestroni, L. Zoli, D. Sciti, $\mathrm{Ti}_{3} \mathrm{SiC}_{2}-\mathrm{Cf}$ composites by spark plasma sintering: processing, microstructure and thermo-mechanical properties, J. Eur. Ceram. Soc. 39 (9) (2019) 2824-2830.

[19] X.B. Deng, X.L. Shi, X.Y. Liu, Y.C. Huang, Z. Yan, K. Yang, Y.F. Wang, Effect of $\mathrm{Ti}_{3} \mathrm{SiC}_{2}$ on tribological properties of M50 matrix self-lubricating composites from 25 to 450 A degrees C, J. Mater. Eng. Perform. 26 (9) (2017) 4595-4604. 
[20] C. Magnus, J. Sharp, W.M. Rain forth, The lubricating properties of spark plasma sintered (SPS) $\mathrm{Ti}_{3} \mathrm{SiC}_{2} \mathrm{MAX}$ phase compound and composite, Tribol. T. (2019) 1-13.

[21] S.B. Li, L.F. Cheng, L.T. Zhang, Oxidation behavior of $\mathrm{Ti}_{3} \mathrm{SiC}_{2}$ at high temperature in air, Mat. Sci. Eng. A-Struct. 341 (1) (2003) 112-120.

[22] G.M. Liu, M.S. Li, Y. Zhang, Y.C. Zhou, Cracking behavior of oxide scale formed on $\mathrm{Ti}_{3} \mathrm{SiC}_{2}$-based ceramic, Mat. Sci. Eng. A-Struct. 360 (1-2) (2003) 408-414.

[23] S. Mazumder, A. Kumar, B.K. Singh, H. Roy, N. Mandal, Tribological investigation of $\mathrm{MgO} / \mathrm{Al}_{2} \mathrm{O}_{3}$ ceramic composite with the inclusion of nano $\mathrm{CuO}$ in dry abrasive wear test, Mater. Res. Express 6 (8) (2019) 085086.

[24] D. Medved, J. Balko, R. Sedlak, A. Kovalcikova, I. Shepa, A. Naughton-Duszova, E. Baczek, M. Podsiadlo, J. Dusza, Wear resistance of $\mathrm{ZrB}_{2}$ based ceramic composites, Int. J. Refract. Met. H. 81 (2019) 214-224.

[25] W.Z. Zhai, K. Zhou, Nanomaterials in superlubricity, Adv. Funct. Mater. 29 (28) (2019) 1806395.

[26] N.N. Zhao, Y.R. Zhao, Y.Q. Wei, X. Wang, J. Li, Y.H. Xu, F.X. Yan, Z.X. Lu, Friction and wear behavior of $\mathrm{TaC}$ ceramic layer formed in-situ on the gray cast iron, Tribol. Int. 135 (2019) 181-188.

[27] S. Sivakumar, B.R. Gollan, K.V. Prajapati, Influence of $\mathrm{ZrB}_{2}$ hard ceramic reinforcement on mechanical and wear properties of aluminum, Ceram. Int. 45 (6) (2019) 7055-7070. 
[28] J.G. Xu, H.B. Yan, D.G. Gu, Friction and wear behavior of polytetrafluoroethylene composites filled with $\mathrm{Ti}_{3} \mathrm{SiC}_{2}$, Ceram. Int. 61 (2014) 270-274.

[29] Y. Zhao, T.B. Yu, C. Guan, J.Y. Sun, X.F. Tan, Microstructure and friction coefficient of ceramic $\left(\mathrm{TiC}\right.$, TiN and $\left.\mathrm{B}_{4} \mathrm{C}\right)$ reinforced $\mathrm{Ni}$-based coating by laser cladding, Ceram. Int. 45 (16) (2019) 20824-20836.

[30] W. Chen, K. Wang, X. Liu, N.R. He, H. Xin, W.H. Hao, Investigation of the friction and wear characteristics of $\mathrm{Si}_{3} \mathrm{~N}_{4}-\mathrm{hBN}$ ceramic composites under marine atmospheric environment, Int. J. Refract. Met. H. 81 (2019) 345-357.

[31] A.G. Steinerian, N.F. Morozov, M.Y. Gutkind, Effect of grain boundary sliding on fracture toughness of ceramic/graphene composites, Mech. Mater. 137 (2019) 103126.

[32] A. Kasyanova, L. Tarutina, J. Lyagaeva, G. Vdovin, D. Medvedev, A. Demin, Thermal and electrical properties of highly dense ceramic materials based on Co-doped $\mathrm{LaYO}_{3}$, JOM-US 71 (11) (2019) 3789-3795.

[33] R. He, Z. Zhou, Z. Qu, X. Cheng, High temperature flexural, tensile strength and oxidation behavior of $\mathrm{Ti}_{3} \mathrm{SiC}_{2}$ ceramic at 900 degrees $\mathrm{C}-1300$ degrees $\mathrm{C}$ in ambient air, J. Test. Eval. 45 (4) (2017) 1150-1158.

[34] A.G. de la Obra, M.J. Sayagues, E. Chicardi, F.J. Gotor, Development of Ti(C,N)-based cermets with ( $\mathrm{Co}, \mathrm{Fe}, \mathrm{Ni})$-based high entropy alloys as binder phase, J. Alloy. Compd. 814 (2020) 152218.

[35] A.G. de la Obra, F.J. Gotor, E. Chicardi, Effect of the impact energy on the 
chemical homogeneity of a $(\mathrm{Ti}, \mathrm{Ta}, \mathrm{Nb})(\mathrm{C}, \mathrm{N})$ solid solution obtained via a mechanically induced self-sustaining reaction, J. Alloy. Compd. 708 (2017) 1008-1017.

[36] S. Hughes, D. Pearce, Investigating sea level rise due to global warming in the teaching laboratory using Archimedes' principle, Eur. J. Phys. 36 (6) (2015) 065033.

[37] S. Madani, N. Charef, A. Hellal, D.L. Garcia, M.F. Garcia, L. Arrar, M.S. Mubarak, Synthesis, density functional theory studies, and sorption properties toward some divalent heavy metal ions of a new polystyrene-supported 4-(5-mercapto-1,3,4-thiadiazol-2-ylimino) pentan-2-one polymer, J. Appl. Polym. Sci. 137 (3) (2020) 48289.

[38] C. Zhang, M.Q. Li, H. Li, The behavior and mechanism of void self-shrinkage in diffusion bonded $1 \mathrm{Cr} 11 \mathrm{Ni} 2 \mathrm{~W} 2 \mathrm{MoV}$ steel joint: Effect of temperature and void morphology, J. Manuf. Process. 35 (2018) 71-78.

[39] L. von Fieandt, K. Johansson, T. Larsson, M. Boman, E. Lindahl, On the growth, orientation and hardness of chemical vapor deposited Ti(C,N), Thin Solid Films 645 (2018) 19-26.

[40] W.M. Maita, E.T. Akinola, Numerical prediction of tensile yield strength and micro hardness of $\mathrm{Ti}_{6} \mathrm{Al}_{4} \mathrm{~V}$ alloy processed by constrained bending and straightening severe plastic deformation, Mater. Res. Express 6 (10) (2019) 106560.

[41] S. Venkatachalam, S. Lenfant, M. Depriester, A.H. Sahraoui, D. Hourlier, Heat 
treatment of commercial polydimethylsiloxane PDMS precursors: Part II. Thermal properties of carbon-based ceramic nanocomposites, Ceram. Int. 45 (17) (2019) 21505-21511.

[42] J.J. Liu, C.Y. Zhu, G.Q. Li, Effect of graphene/graphene oxide on wear resistance and thermal conductivity of Co-Ni coatings, JOM-US (2019) 10.1007/s11837-019-03865-2.

[43] X.Y. Liu, X.L. Shi, Y.C. Huang, X.B. Deng, G.C. Lu, Z. Yan, B. Xue, Tribological behavior and self-healing functionality of M50 material covered with surface micropores filled with Sn-Ag-Cu, Tribol. Int. 128 (2018) 365-375.

[44] H.Z. Li, W.P. Tong, C. Ma, L.Q. Chen, L. Zuo, Abrasive wear behaviors of high-vanadium alloy steel using the dry sand/rubber wheel apparatus, P. I. Mech. Eng. J-J. Eng. 233 (12) (2019) 1800-1809.

[45] S. Mazumder, B.B. Barad, B.K. Show, N. Mandal, Tribological property enhancement of 3Y-TZP ceramic by the combined effect of $\mathrm{CaF}_{2}$ and $\mathrm{MgO}$ phases, Ceram. Int. 45 (10) (2019) 13447-13455.

[46] A. Radhi, V. Iacobellis, K. Behdinan, A passive oxidation, finite element kinetics model of an ultra-high temperature ceramic composite, Compos. Part B-Eng. 175 (2019) 107129.

[47] L.L. Zheng, Q.S. Hua, X.C Li, M.S. Li, Y.H. Qian, J.J. Xu, J.M. Zhang, Z.M. Zheng, Z.Q. Dai, H.X. Zhang, Investigation on the effect of $\mathrm{Nb}$ doping on the oxidation mechanism of $\mathrm{Ti}_{3} \mathrm{SiC}_{2}$, Corros. Sci. 140 (2018) 374-378.

[48] M. Haftani, M.S. Heydari, H.R. Baharvandi, N. Ehsani, Studying the oxidation 
of $\mathrm{Ti}_{2} \mathrm{AlC}$ MAX phase in atmosphere: A review, Int. J. Refract. Met. H. 61 (2016) $51-60$.

[49] N.V. Sevost'yanov, O.V. Basargin, V.G. Maksimov, N.P. Burkovskaya, High-temperature oxidation of $\mathrm{Ti}_{3} \mathrm{SiC}_{2}$-based materials prepared by spark plasma sintering, Inorg. Mater. 55 (1) (2019) 9-13.

[50] D.A. Fischer, I.T. Vargas, G.E. Pizarro, F. Armijo, M. Walczak, The effect of scan rate on the precision of determining corrosion current by Tafel extrapolation: A numerical study on the example of pure $\mathrm{Cu}$ in chloride containing medium, Electrochim. ACTA 313 (2019) 457-467.

[51] X.W. Li, T. Shi, B. Li, X.C. Chen, C.W. Zhang, Z.G. Guo, Q.X. Zhang, Subtractive manufacturing of stable hierarchical micro-nano structures on AA5052 sheet with enhanced water repellence and durable corrosion resistance, Mater. Design 183 (2019) 108152. 
Table 1 Average granularities and purities of raw materials used in this work.

\begin{tabular}{ccc}
\hline Powder & Granularity (mesh) & Purity (wt.\%) \\
\hline $\mathrm{Ti}$ & 400 & 99.9 \\
$\mathrm{TiC}$ & 400 & 99.9 \\
$\mathrm{SiC}$ & 400 & 99.0 \\
$\mathrm{Al}$ & 400 & 99.0 \\
$\mathrm{Ti}(\mathrm{C}, \mathrm{N})$ & 400 & 99.0 \\
\hline
\end{tabular}




\section{Figure Captions}

Fig. 1. SEM image and XRD pattern of $\mathrm{Ti}_{3} \mathrm{SiC}_{2}$ powders.

Fig. 2. (a) $\mathrm{XRD}$ patterns of $\mathrm{Ti}_{3} \mathrm{SiC}_{2} / \mathrm{Ti}(\mathrm{C}, \mathrm{N})$ composites sintered at $1400{ }^{\circ} \mathrm{C}$ with different $\mathrm{Ti}(\mathrm{C}, \mathrm{N})$ mass fractions. (b) XRD patterns of $\mathrm{Ti}_{3} \mathrm{SiC}_{2} / \mathrm{Ti}(\mathrm{C}, \mathrm{N})$ composites sintered with $20 \mathrm{wt} \% \mathrm{Ti}(\mathrm{C}, \mathrm{N})$ at various temperatures. (c) SEM image and (d-e) cross-section $\mathrm{SEM}$ images of $\mathrm{Ti}_{3} \mathrm{SiC}_{2} / \mathrm{Ti}(\mathrm{C}, \mathrm{N})$ composite sintered at $1400{ }^{\circ} \mathrm{C}$ with 20 $\mathrm{wt} \% \operatorname{Ti}(\mathrm{C}, \mathrm{N})$.

Fig. 3. (a) Measured densities and relative densities of $\mathrm{Ti}_{3} \mathrm{SiC}_{2} / \mathrm{Ti}(\mathrm{C}, \mathrm{N})$ composites sintered with $20 \mathrm{wt} \% \mathrm{Ti}(\mathrm{C}, \mathrm{N})$ at different temperatures. (b) Measured densities and relative densities of $\mathrm{Ti}_{3} \mathrm{SiC}_{2} / \mathrm{Ti}(\mathrm{C}, \mathrm{N})$ composites sintered at $1400{ }^{\circ} \mathrm{C}$ with various $\operatorname{Ti}(\mathrm{C}, \mathrm{N})$ mass fractions.

Fig. 4. (a) Relationship between sintering temperature and micro hardness of $\mathrm{Ti}_{3} \mathrm{SiC}_{2} / \mathrm{Ti}(\mathrm{C}, \mathrm{N})$ composites with $20 \mathrm{wt} \% \mathrm{Ti}(\mathrm{C}, \mathrm{N})$. (b) Micro hardness of $\mathrm{Ti}_{3} \mathrm{SiC}_{2} / \mathrm{Ti}(\mathrm{C}, \mathrm{N})$ composites sintered at $1400{ }^{\circ} \mathrm{C}$ with different $\mathrm{Ti}(\mathrm{C}, \mathrm{N})$ mass fractions.

Fig. 5. (a) Instantaneous friction coefficients versus friction time for $\mathrm{Ti}_{3} \mathrm{SiC}_{2} / \mathrm{Ti}(\mathrm{C}, \mathrm{N})$ composites with different $\operatorname{Ti}(\mathrm{C}, \mathrm{N})$ contents at a low speed of $0.1 \mathrm{~m} / \mathrm{s}$ and a light load of $5 \mathrm{~N}$. (b) Instantaneous friction coefficients versus time for $\mathrm{Ti}_{3} \mathrm{SiC}_{2} / \mathrm{Ti}(\mathrm{C}, \mathrm{N})$ 


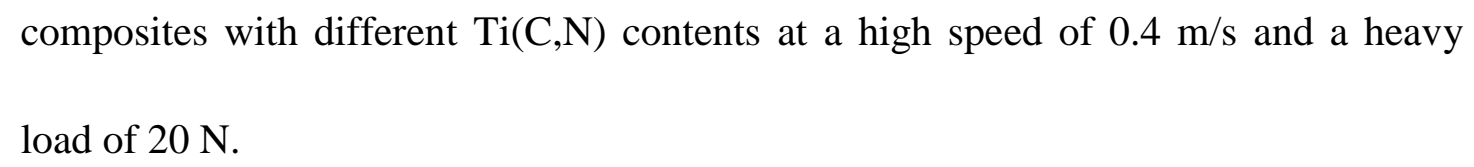

Fig. 6. (a) Friction coefficients and (b) wear rates versus $\mathrm{Ti}(\mathrm{C}, \mathrm{N})$ contents for composites at different speeds and loads.

Fig. 7. SEM images of frictional composites with $\mathrm{Ti}(\mathrm{C}, \mathrm{N})$ contents of (a) $5 \mathrm{wt} \%$ and (b) $20 \mathrm{wt} \%$ under a low speed $(0.1 \mathrm{~m} / \mathrm{s})$ and light load $(5 \mathrm{~N})$ condition.

Fig. 8. SEM images and EDS spectra of frictional composites with $\mathrm{Ti}(\mathrm{C}, \mathrm{N})$ contents of (a, c) $5 \mathrm{wt} \%$ and $(\mathrm{b}, \mathrm{d}) 20 \mathrm{wt} \%$ under a high speed $(0.4 \mathrm{~m} / \mathrm{s})$ and heavy load $(20 \mathrm{~N})$ condition.

Fig. 9. (a) Friction coefficients and (b) wear rates versus applied loads for composites with $20 \mathrm{wt} \% \mathrm{Ti}(\mathrm{C}, \mathrm{N})$ at different rotation speeds.

Fig. 10. SEM images and EDS spectra of frictional composites with $20 \mathrm{wt} \% \mathrm{Ti}(\mathrm{C}, \mathrm{N})$ and $20 \mathrm{~N}$ load at speeds of (a, c) $0.1 \mathrm{~m} / \mathrm{s}$ and $(\mathrm{b}, \mathrm{d}) 0.2 \mathrm{~m} / \mathrm{s}$.

Fig. 11. SEM images, enlarged images and EDS spectra of frictional composites with $20 \mathrm{wt} \% \mathrm{Ti}(\mathrm{C}, \mathrm{N})$ and $0.3 \mathrm{~m} / \mathrm{s}$ rotation speed at loads of (a, c, e) $5 \mathrm{~N}$ and $(\mathrm{b}, \mathrm{d}, \mathrm{f}) 15 \mathrm{~N}$. 
Fig. 12. Relationship between mass increments $(\Delta W)$ and oxidation cycle times of $\mathrm{Ti}_{3} \mathrm{SiC}_{2} / \mathrm{Ti}(\mathrm{C}, \mathrm{N})$ composites with $20 \mathrm{wt} \% \mathrm{Ti}(\mathrm{C}, \mathrm{N})$ at different oxidation temperatures.

Fig. 13. (a) XRD patterns of oxide layers on $\mathrm{Ti}_{3} \mathrm{SiC}_{2} / \mathrm{Ti}(\mathrm{C}, \mathrm{N})$ composites after 40 oxidation cycles at different temperatures. (b) XRD patterns of oxide layers on $\mathrm{Ti}_{3} \mathrm{SiC}_{2} / \mathrm{Ti}(\mathrm{C}, \mathrm{N})$ composites after various oxidation cycles at $1000{ }^{\circ} \mathrm{C}$.

Fig. 14. $\mathrm{SEM}$ images of oxide layers on $\mathrm{Ti}_{3} \mathrm{SiC}_{2} / \mathrm{Ti}(\mathrm{C}, \mathrm{N})$ composites after 40 oxidation cycles at (a) $800{ }^{\circ} \mathrm{C}$, (b) $1000{ }^{\circ} \mathrm{C}$ and (c) $1200{ }^{\circ} \mathrm{C}$. EDS spectra of oxide layers on $\mathrm{Ti}_{3} \mathrm{SiC}_{2} / \mathrm{Ti}(\mathrm{C}, \mathrm{N})$ composites after 40 oxidation cycles at (d) $800{ }^{\circ} \mathrm{C}$ and (e) $1200{ }^{\circ} \mathrm{C}$.

Fig. 15. Cross-section $\mathrm{SEM}$ images of oxide layers on $\mathrm{Ti}_{3} \mathrm{SiC}_{2} / \mathrm{Ti}(\mathrm{C}, \mathrm{N})$ composites after 40 oxidation cycles at (a) $800{ }^{\circ} \mathrm{C}$, (b) $1000{ }^{\circ} \mathrm{C}$ and (c) $1200{ }^{\circ} \mathrm{C}$.

Fig. 16. (a) Polarization curves and (b) electrochemical impedance spectra of $\mathrm{Ti}_{3} \mathrm{SiC}_{2} / \mathrm{Ti}(\mathrm{C}, \mathrm{N})$ composites sintered at $1400{ }^{\circ} \mathrm{C}$ with various $\mathrm{Ti}(\mathrm{C}, \mathrm{N})$ mass fractions in $3.5 \mathrm{wt} \% \mathrm{NaCl}$ solution. 


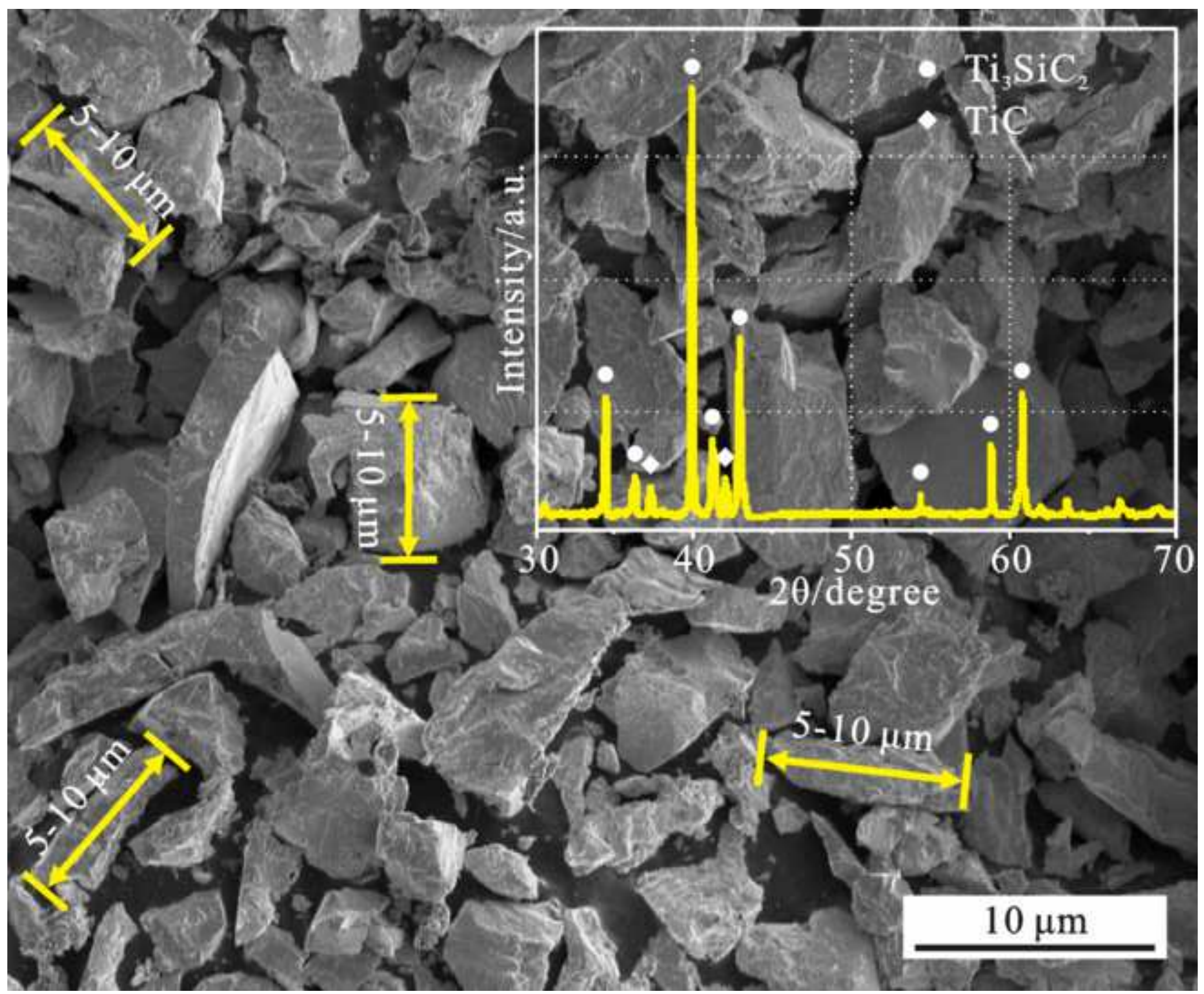



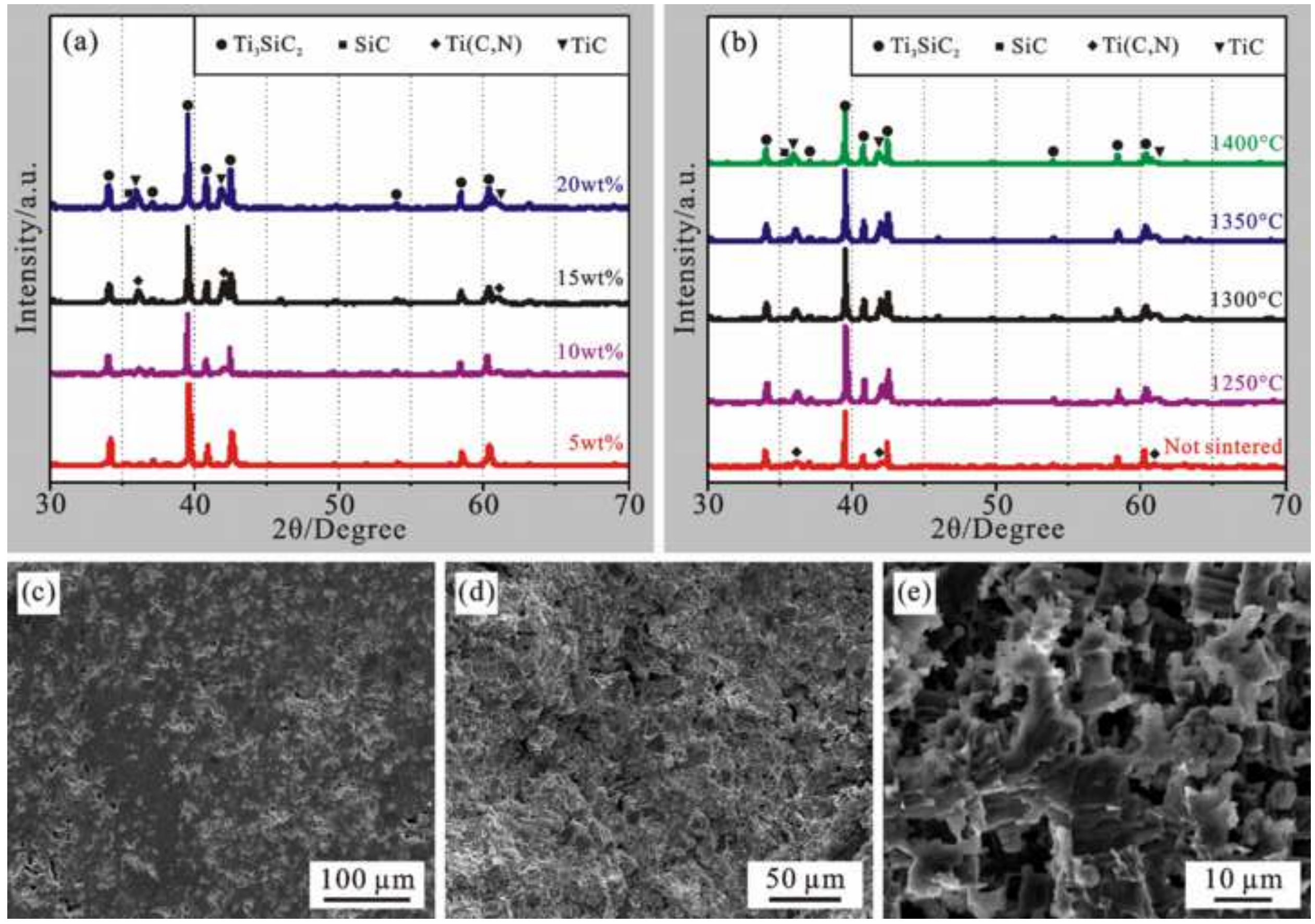

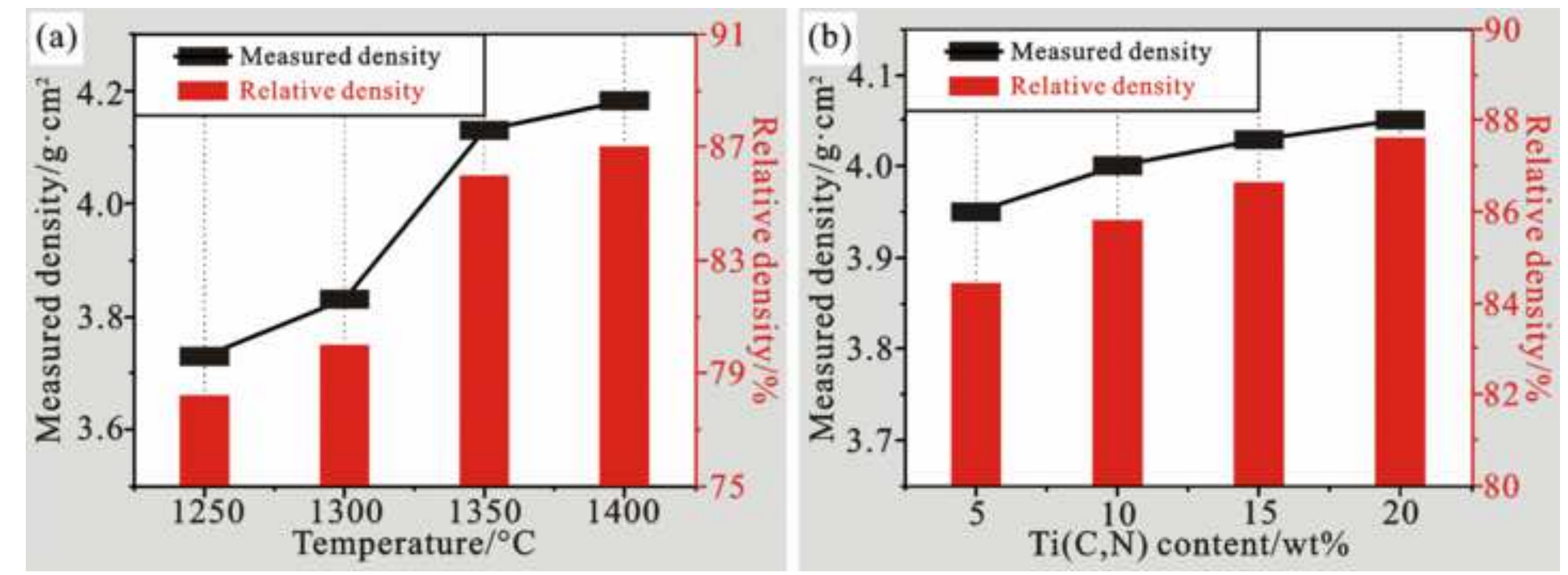

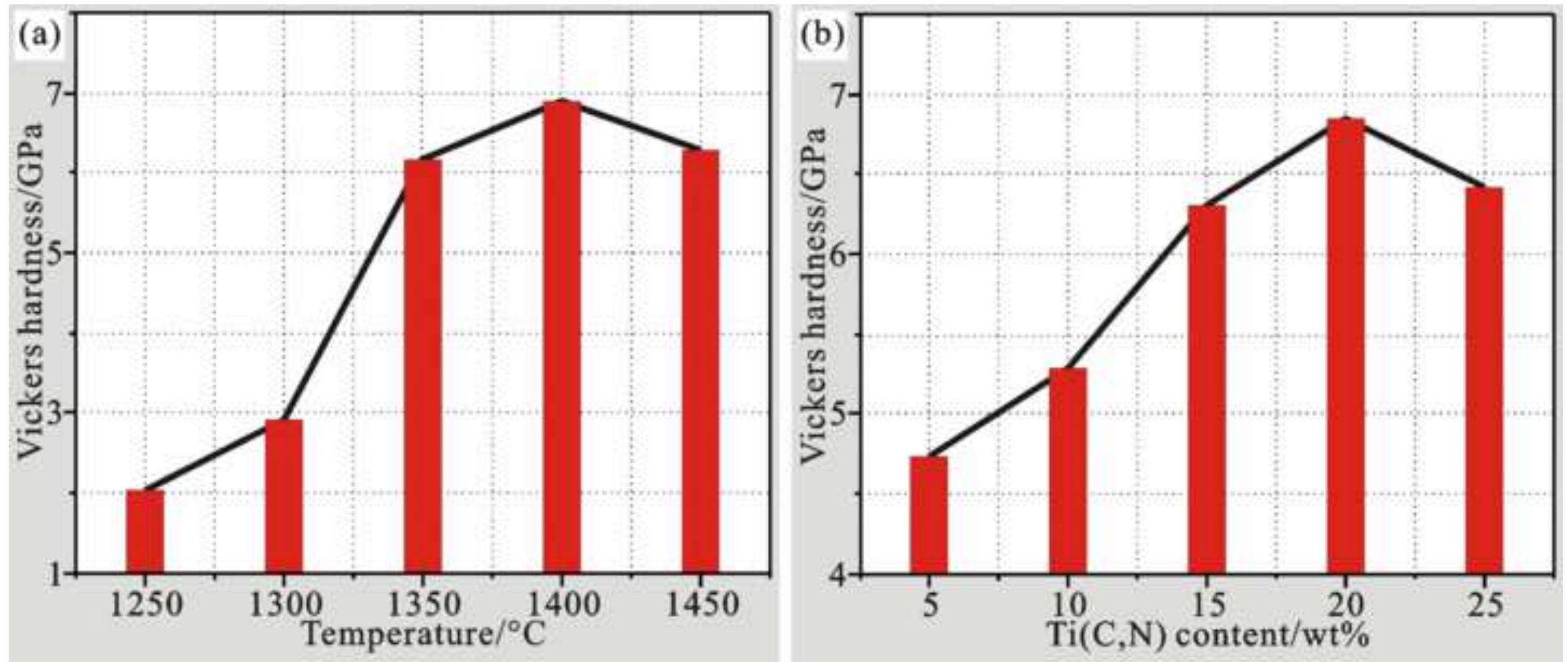

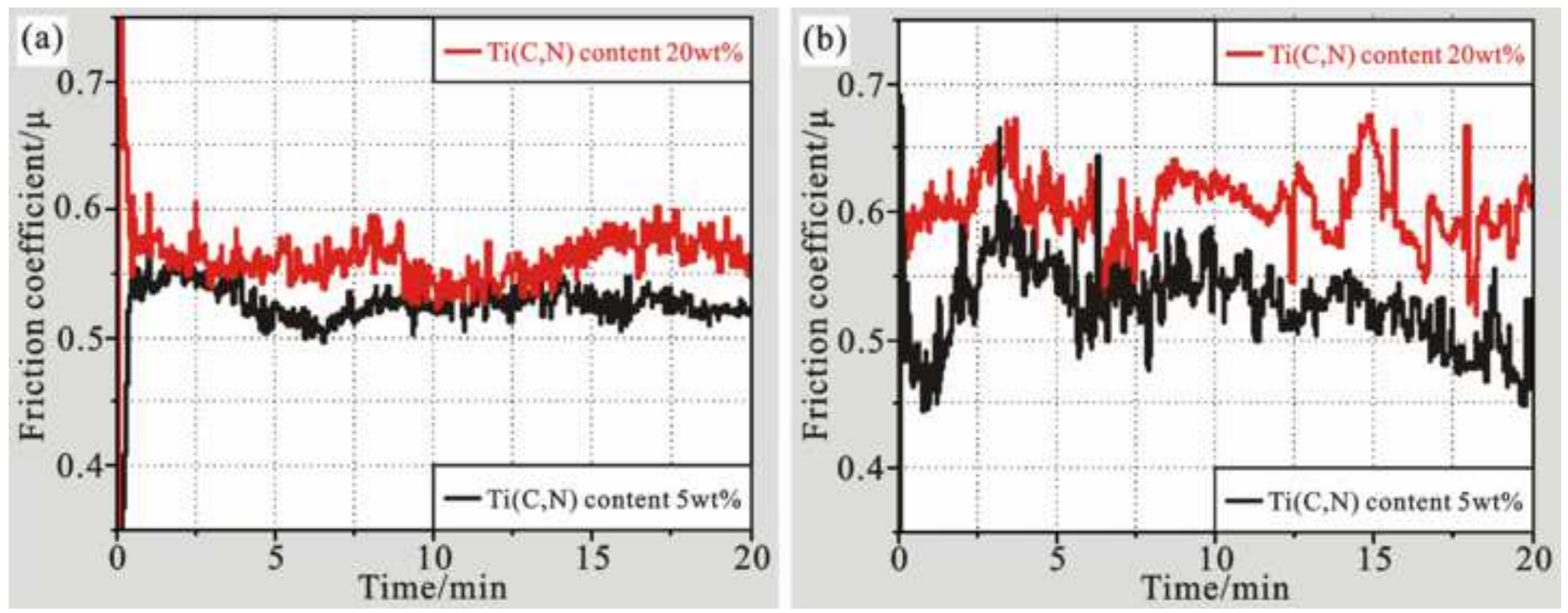

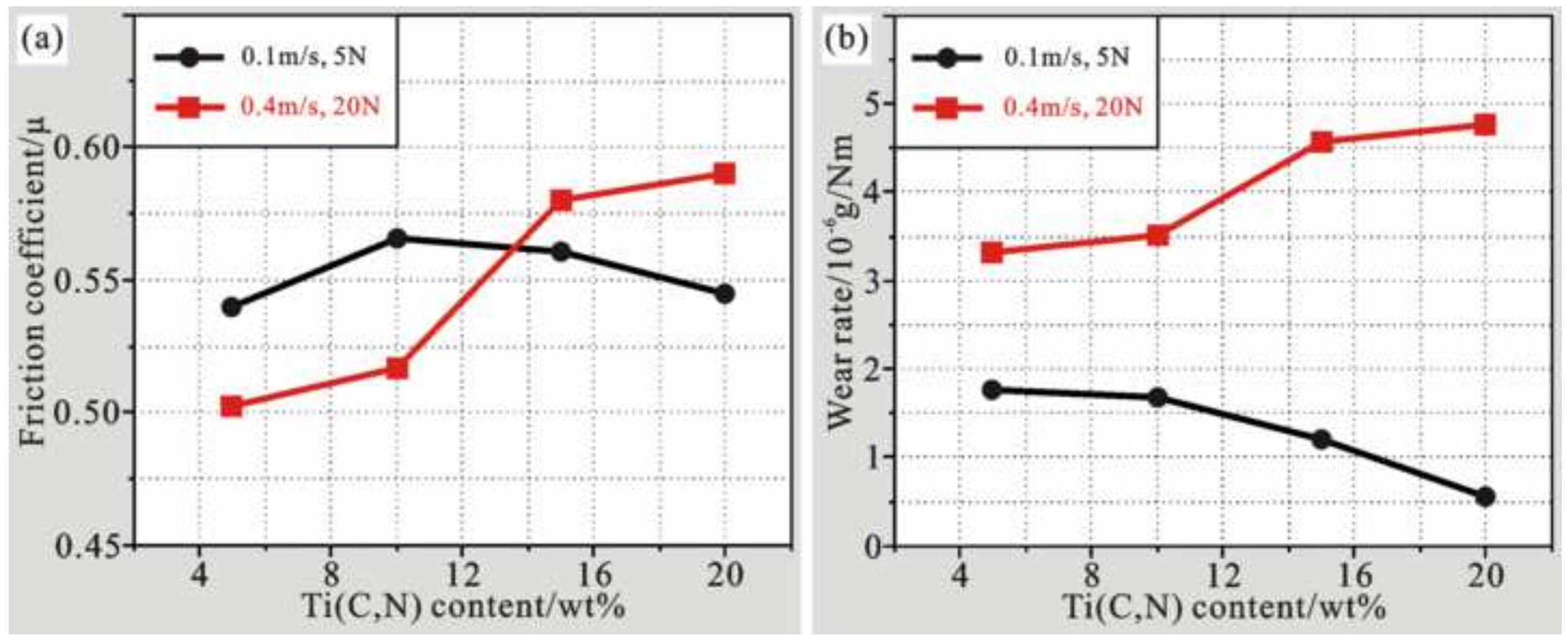
Click here to download high resolution image
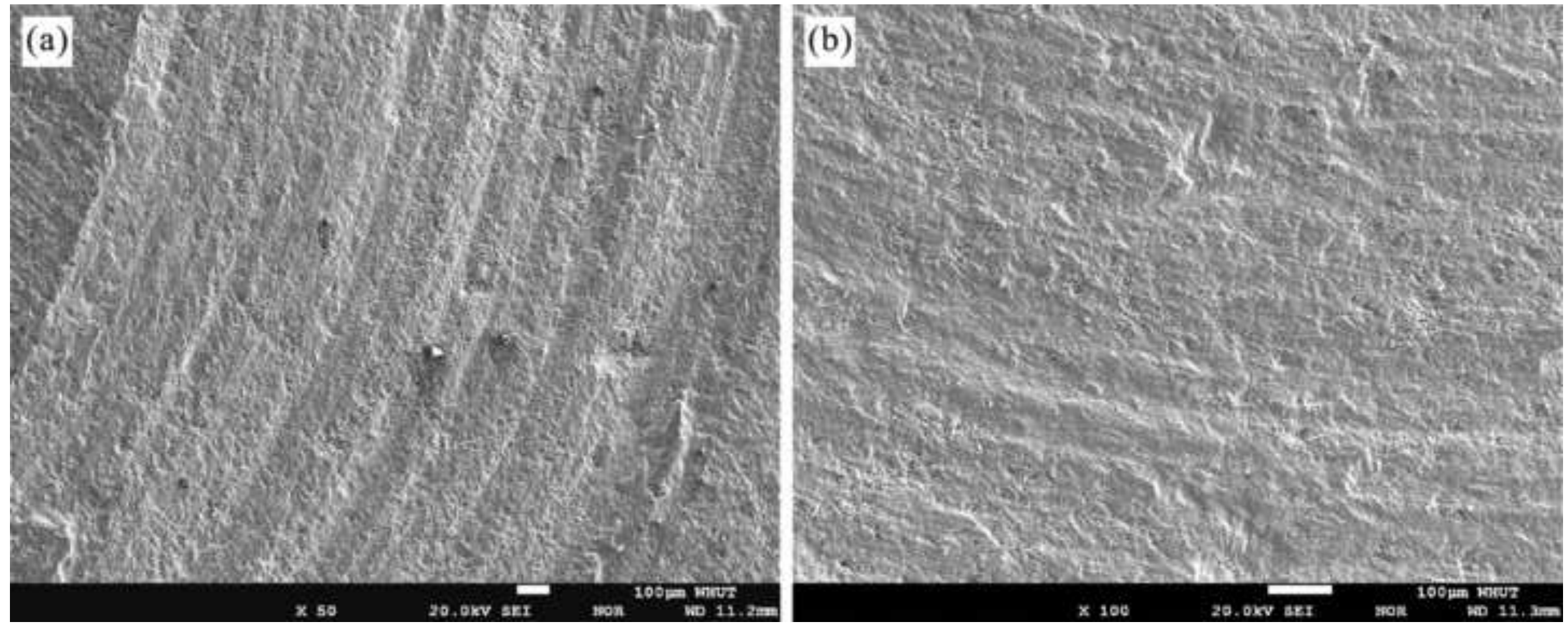
Click here to download high resolution image
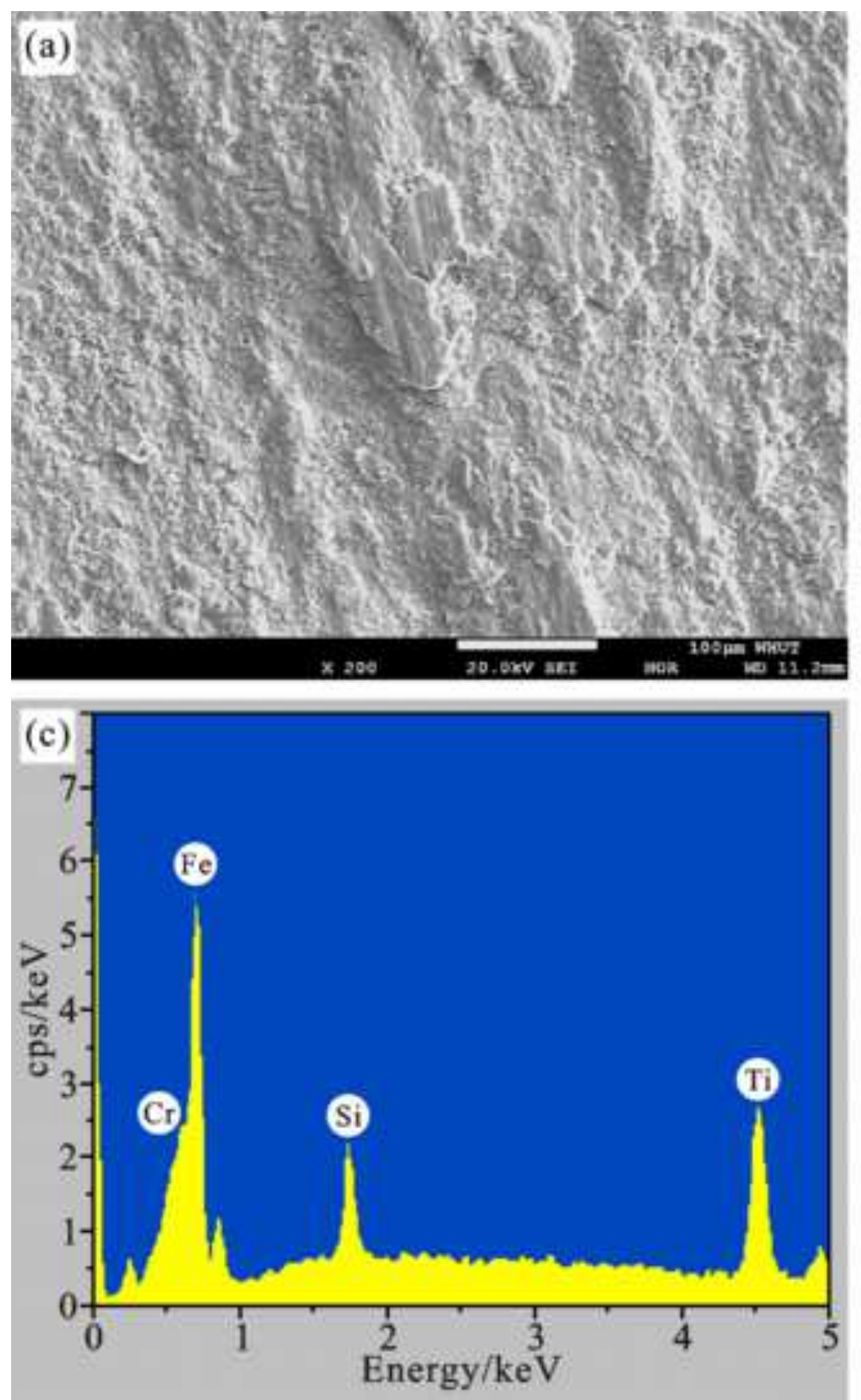
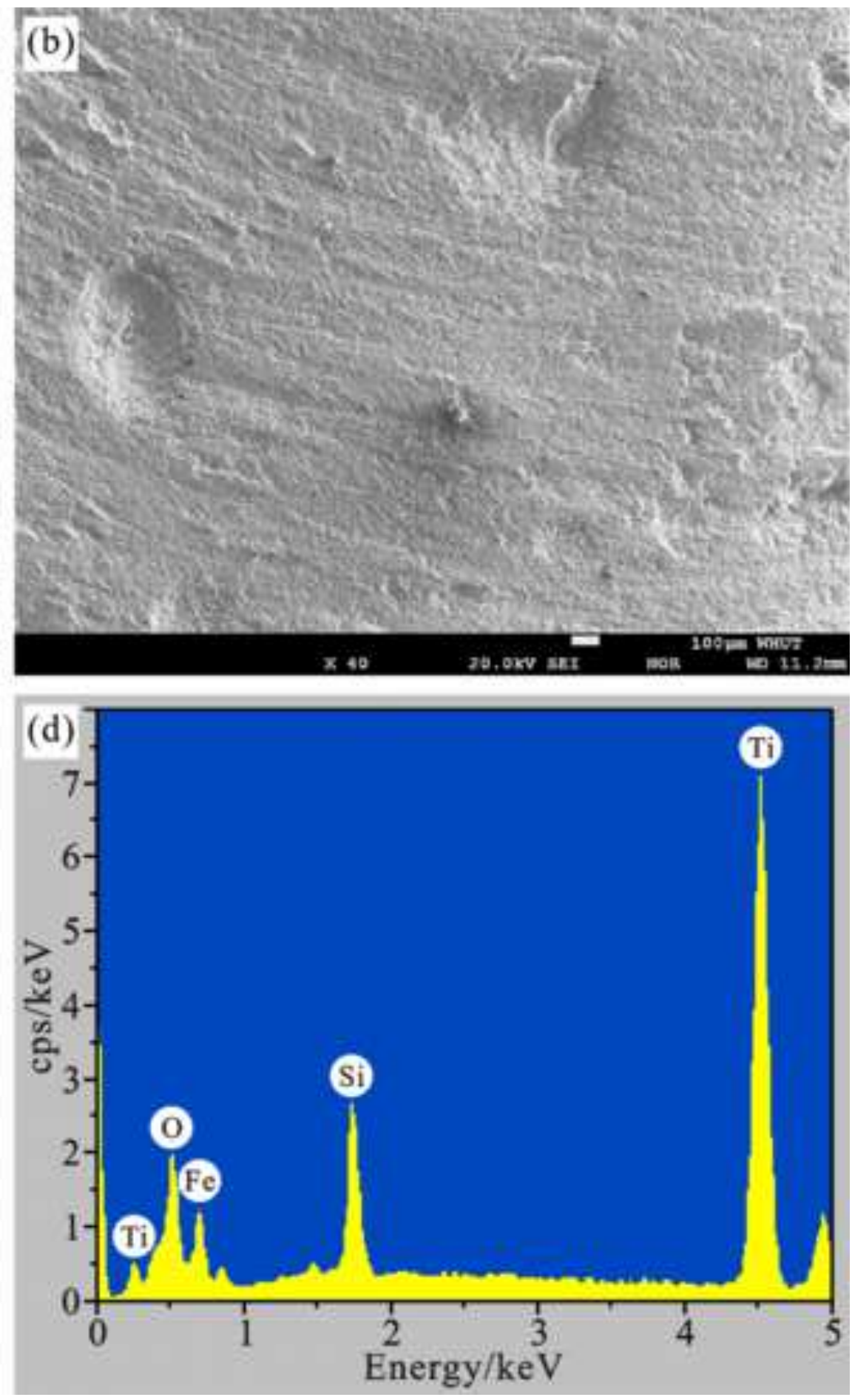

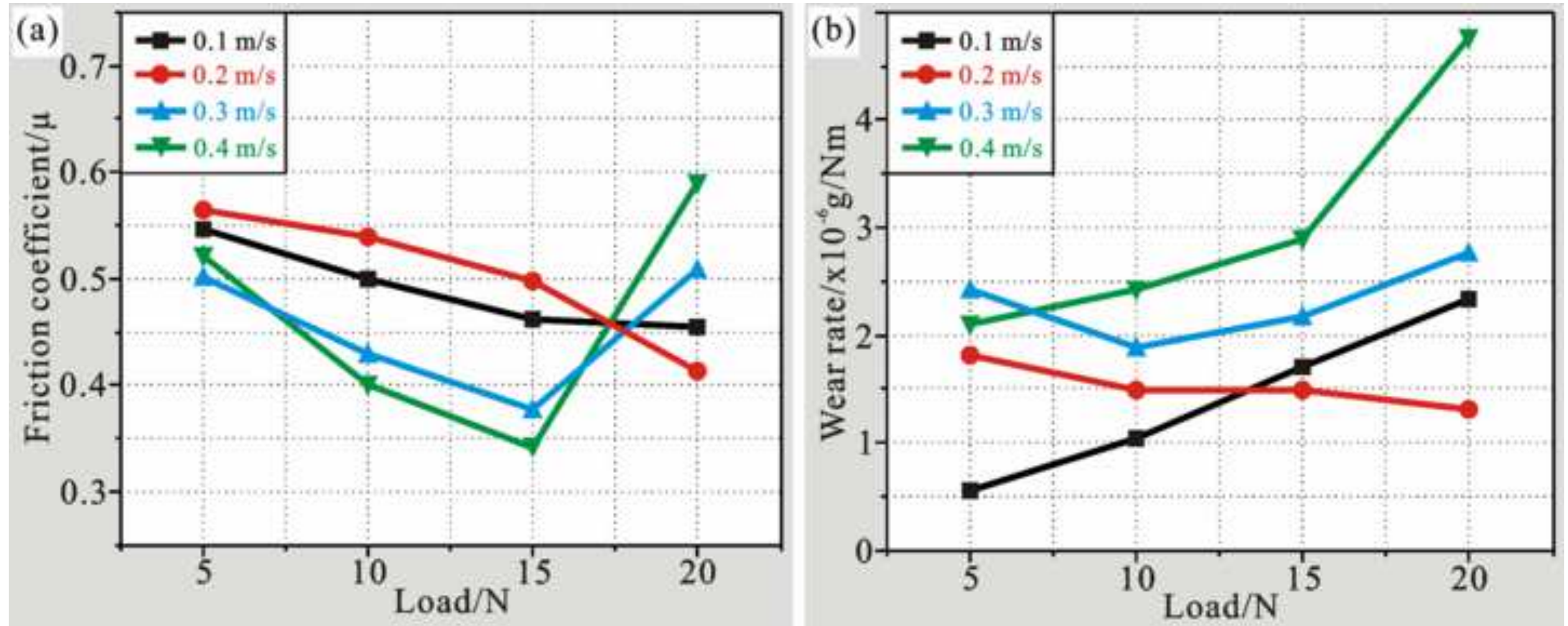

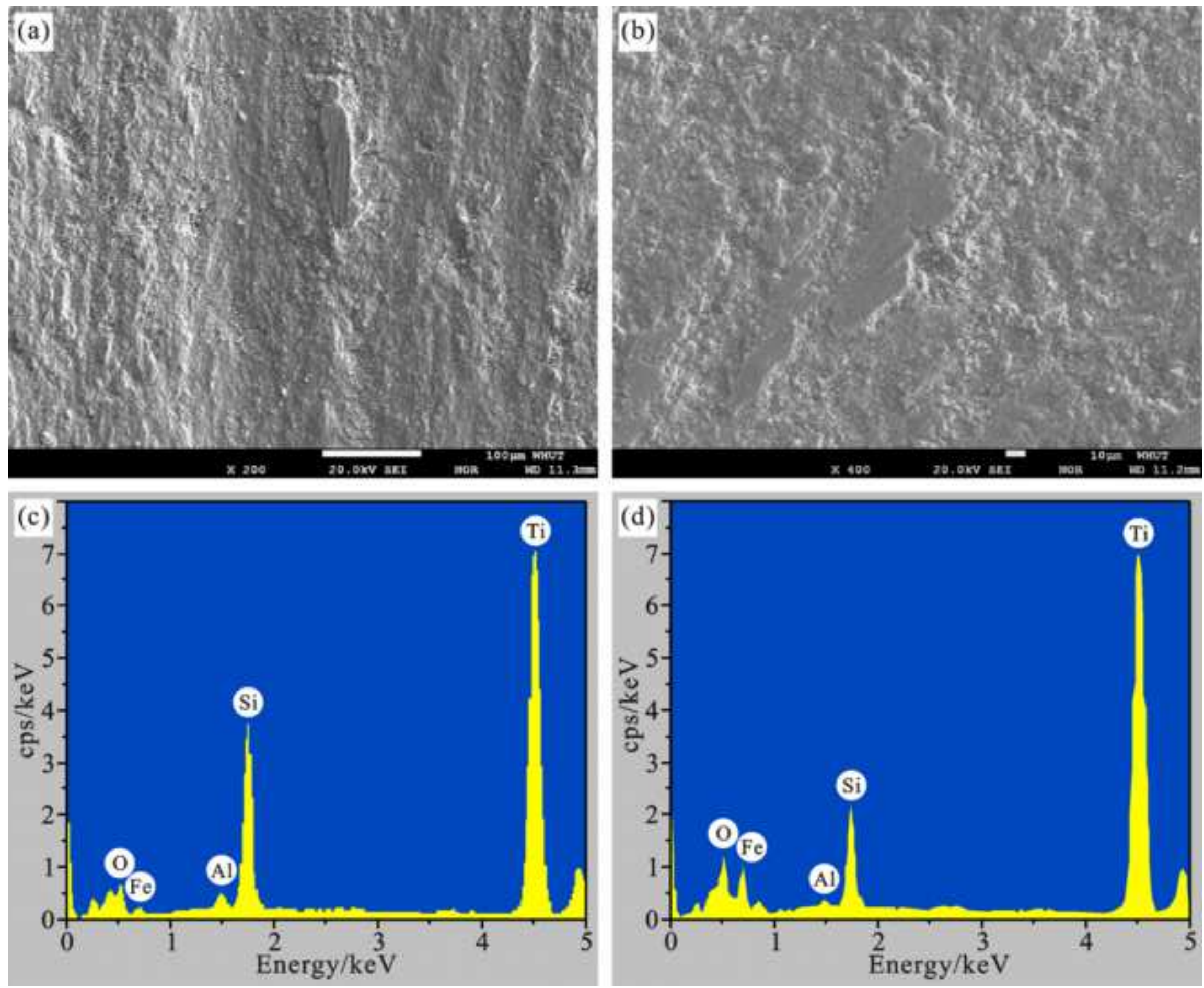
Click here to download high resolution image
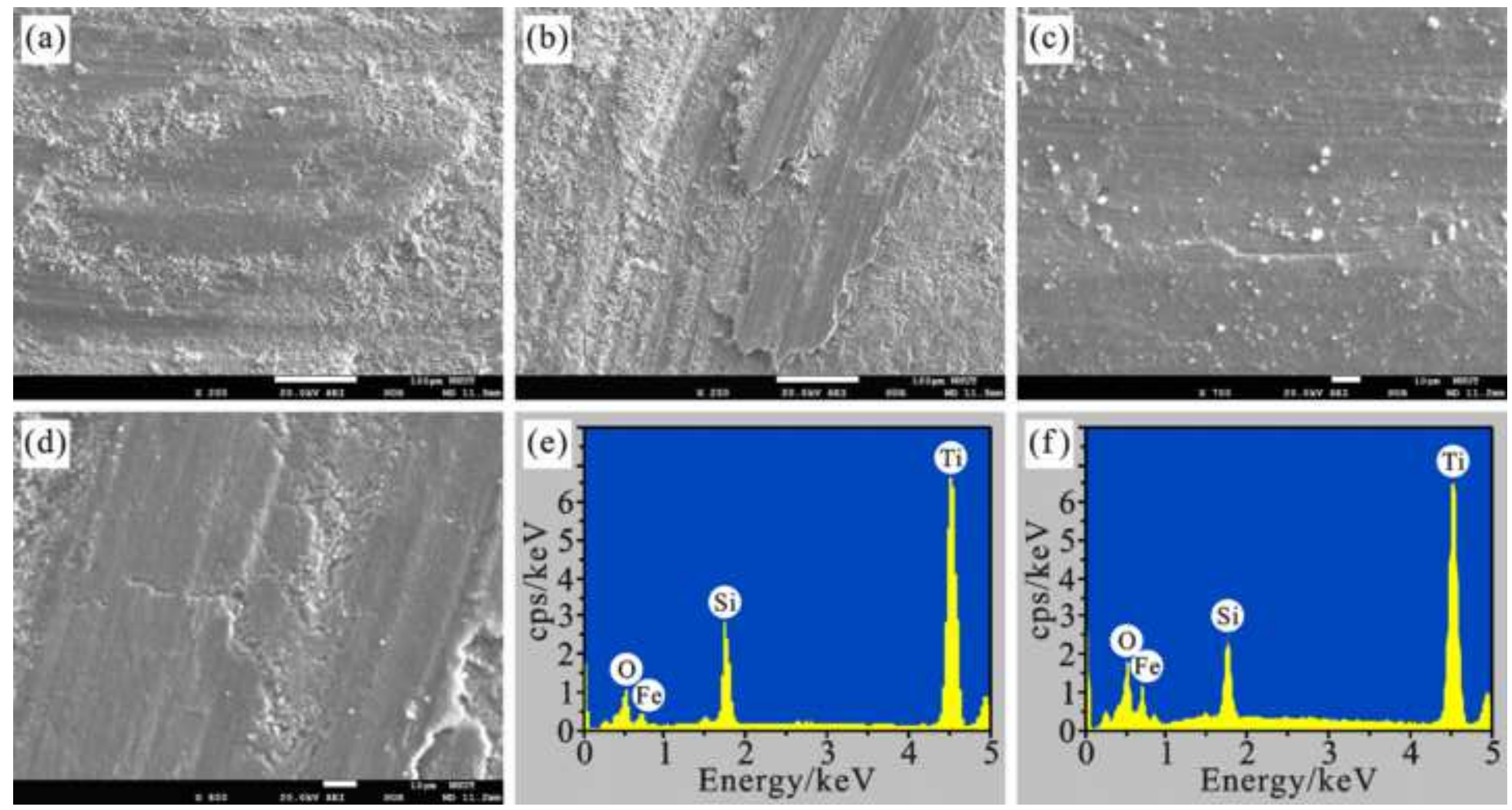
Figure 12
Click here to download high resolution image

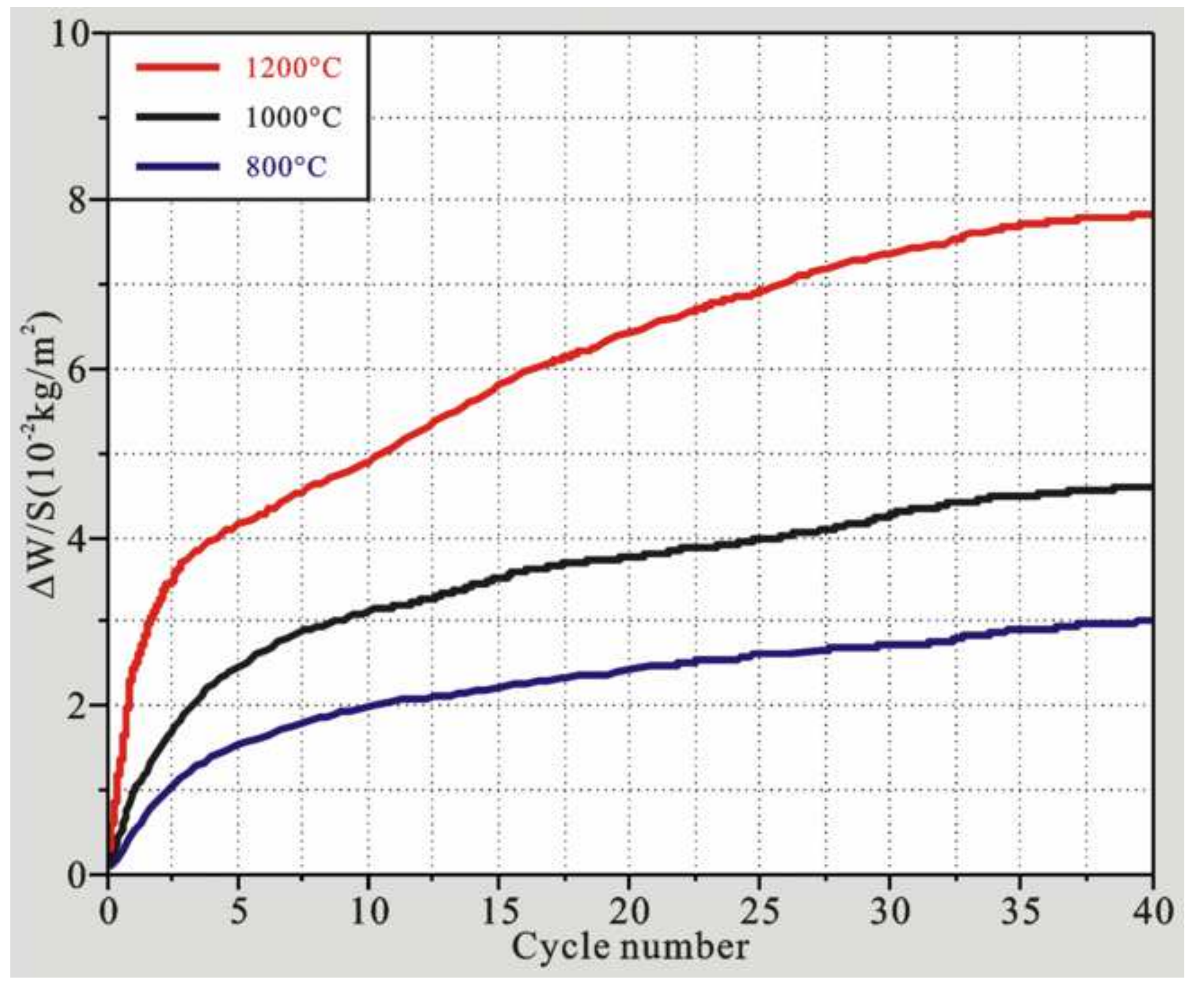



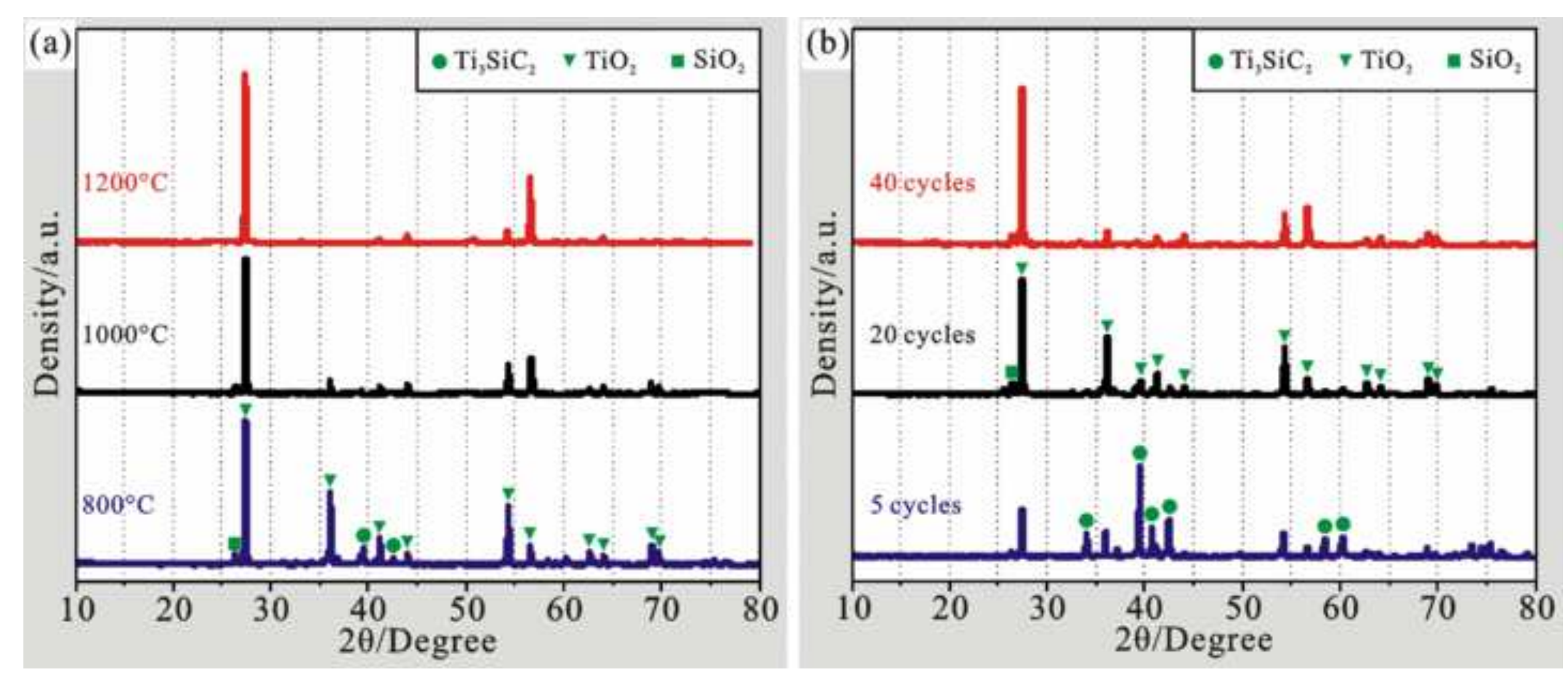

Click here to download high resolution image 
Click here to download high resolution image
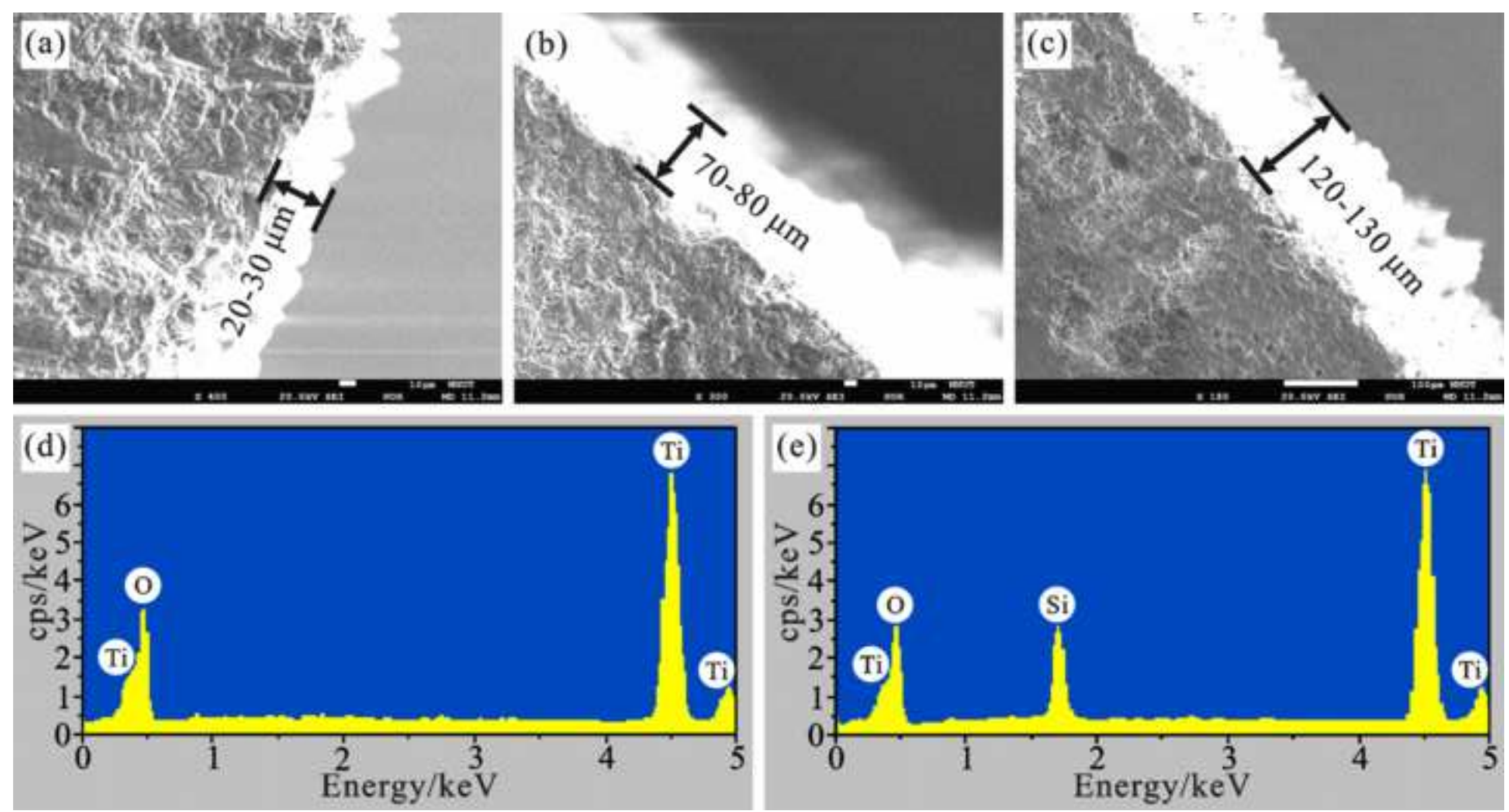
Click here to download high resolution image
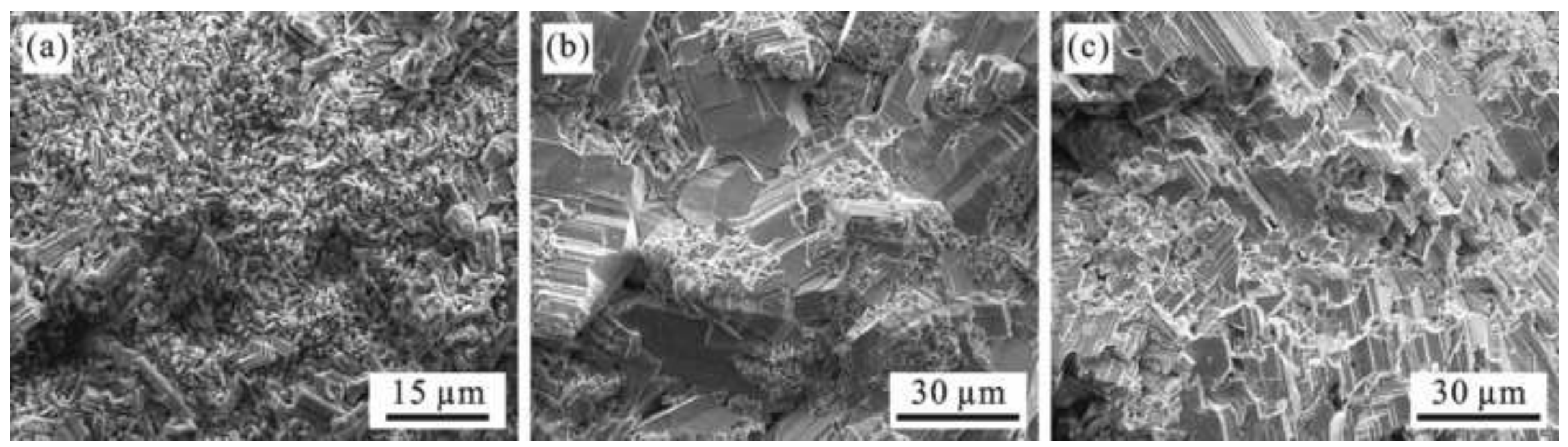

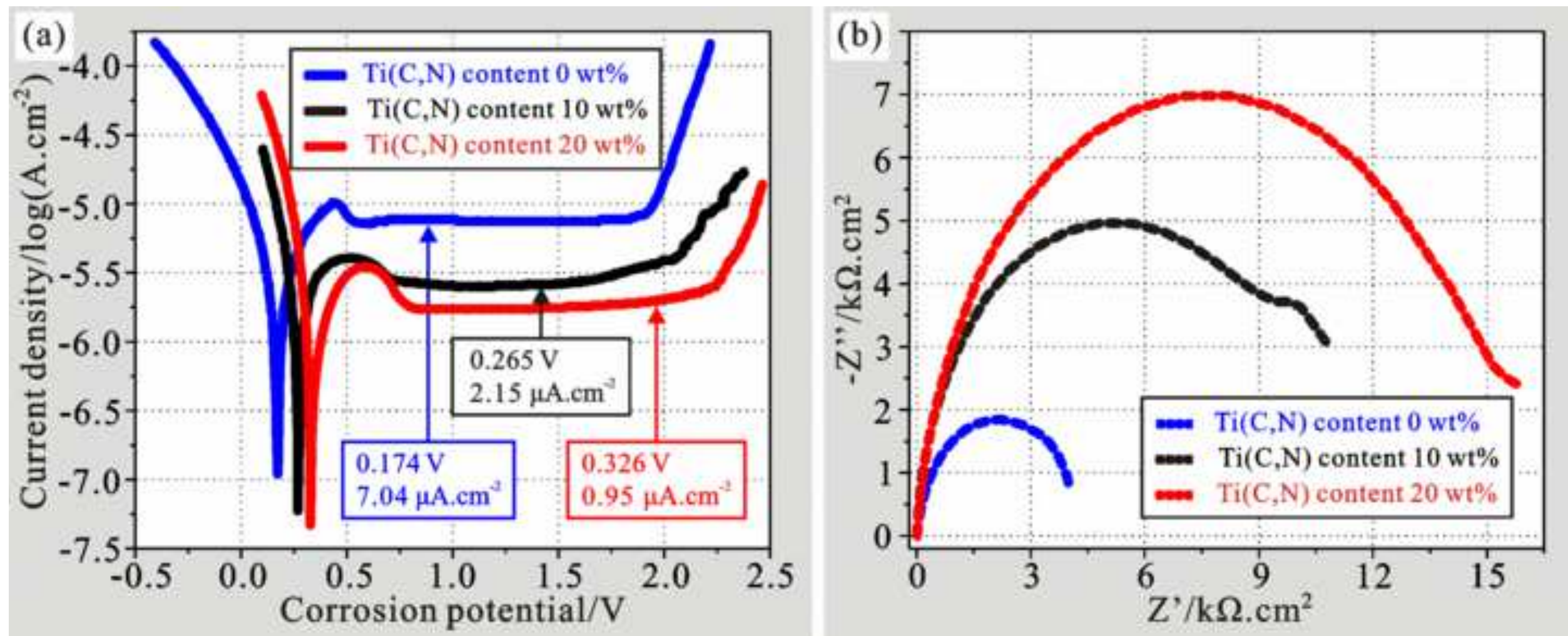


\section{Declaration of interests}

The authors declare that they have no known competing financialinterestsor personal relationships that could have appeared to influence the work reported in this paper.

$\square$ The authors declare the following financial interests/personal relationships which may be considered as potential competing interests:

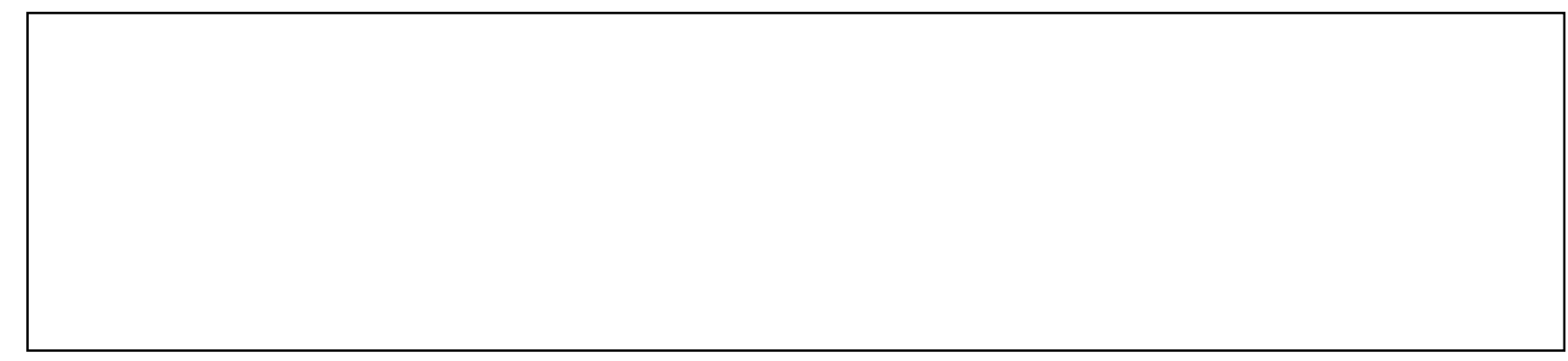

